\title{
Effect of FDI on Pollution in China: New Insights Based on Wavelet Approach
}

\author{
Wen Jun ${ }^{1}$, Muhammad Zakaria ${ }^{1, *}$, Syed Jawad Hussain Shahzad ${ }^{2}\left(\mathbb{D}\right.$ and Hamid Mahmood ${ }^{1(1)}$ \\ 1 School of Economics and Finance, Xi'an Jiaotong University, Xi'an 710049, China; \\ wjun19781127@xjtu.edu.cn (W.J.); hamid.xjtu@gmail.com (H.M.) \\ 2 Energy and Sustainable Development, Montpellier Business School, 34080 Montpellier, France; \\ j.syed@montpellier-bs.com \\ * Correspondence: mzakaria80@hotmail.com
}

Received: 18 September 2018; Accepted: 5 October 2018; Published: 24 October 2018

\begin{abstract}
By applying the wavelet tool, this study examines the effect of foreign direct investment (FDI) on pollution in China, for the period 1982 to 2016. Carbon dioxide and sulfur dioxide emissions are used as pollution variables. The results reveal that FDI positively affected pollution at high frequency (short term) during the 1980s and after 2000, and at low frequency (long term) but not at medium frequency (medium term) for the entire time period. It demonstrates that FDI increases pollution both in the short and long term, but not in the medium term. It indicates that FDI has created pollution havens in China. For robustness analysis, spectral causality test was applied. The results of this causality test indicate that FDI causes $\mathrm{CO}_{2}$ emissions both in the short-run and long-run. This suggests that in China FDI predicts $\mathrm{CO}_{2}$ emissions. Thus, stringent environmental rules are required to restrict the inflows of foreign dirty industries in China.
\end{abstract}

Keywords: FDI; pollution; China; wavelet

\section{Introduction}

For sustainable economic development, improvement in environmental quality is indispensable. There are different factors which affect environmental quality, such as economic growth, industrial production, energy consumption, financial development, etc. Besides national economic activities, international economic activities also affect the environment. So, there is a need to examine interrelations between transboundary economic activities such as capital flows, trade, finance, transport, etc. and domestic environment. Foreign direct investment (FDI) is also an international activity which is indispensable for economic growth, however, it also affects the environment of the host country. FDI inflows increase domestic production, which increases the burning of fossil fuels in domestic industries. It increases the pollution levels, which deteriorates the environmental quality.

There are basically two competing theories regarding the impact of FDI on environmental quality in host country i.e., the pollution haven hypothesis and the pollution halo hypothesis [1,2]. Pollution haven hypothesis stipulates that FDI aggravates pollution in developing countries because these countries attract foreign investment by lowering their environmental standards. Empirically, many studies have supported the pollution haven hypothesis (see e.g., [3-12]). In turn, some studies have criticized the pollution haven hypothesis and have not supported this hypothesis $[13,14]$. According to the pollution halo hypothesis, FDI transfers high technology and diffuses best management practices in the host countries, which create pollution halos to reduce pollution by exerting positive externalities. Many empirical studies have also supported the pollution halo hypothesis $[7,15,16]$.

FDI affects environmental quality through different channels i.e., scale effect, composition effect and technique effect [17]. According to scale effect, FDI increases pollution by simply scaling-up the 
economy, ceteris paribus [15]. The composition (structural) effect stipulates that FDI can increase or decrease pollution by changing the pattern of economic activity [18]. For instance, if foreign firms use labor-intensive (capital-intensive) production methods, then pollution will decrease (increase). The technique effect postulates that foreign firms may bring more environmentally friendly techniques, which will also have spillover for local firms [19]. It will improve the environment by reducing emission as resources will be efficiently utilized, and thereby less pollution will be emitted. FDI also affects pollution through another channel, which is called income effect. According to this effect when income increases due to FDI, people demand more stringent regulations and high environmental standards, which reduces pollution. Thus, the effect of FDI on pollution is complex and depends upon which effect dominates the other effects. If the technology effect dominates then FDI will decrease pollution. However, if scale effect dominates then pollution will increase with FDI.

This theoretical trade-off has stimulated researchers to empirically investigate the effect of FDI on the environment in the host country. Some studies have shown that FDI inflows increase pollution $[9,16,20,21]$, while others have shown that FDI inflows reduce pollution [22-24]. Thus, like theoretical literature, empirical literature has also provided mixed results about the impact of FDI on environment in the host country. Empirical findings in China have also shown mixed results. Some studies have shown that FDI has turned China into a pollution haven as it has deteriorated the environment by contributing to pollution, while other studies have supported the pollution halo hypothesis and have shown that FDI has improved the environment by decreasing pollution through transfer of technology. Section 3 provides the literature review for China in detail.

Although some studies have been conducted to examine the effect of FDI on the environment in China, more empirical analysis is required for several reasons. Firstly, empirical literature has provided contradictory results for the effect of FDI on the environment in China. Thus, there is a need to re-examine the association between FDI and the environment. Secondly, almost all studies in China have used panel data, but examining the FDI-environment link using time series data for China will provide useful policy implications. The advantage of time series analysis is that it is useful for explanative analysis, that is, it helps to study cross-correlation and relationship between two time-series and their dependence on each other. Furthermore, time series analysis helps to understand the past and to predict the future. Thirdly, previous studies in China have used traditional analysis techniques such as regression analysis using OLS, panel fixed effect, random effect, Generalized Method of Moments (GMM), etc. This study is the first study which will use the wavelet coherence technique to examine the FDI-environment linkages. The wavelet coherence approach helps to identify the lead-lag relationship between the variables over time and across frequencies. The latter aspect highlights the dependence dynamics of variables from a short, medium and long run perspective, and thus assists in formulating the policies accordingly. Fourthly, previous studies have used annual data for the analysis, while the present will use quarterly frequencies for empirical analysis. The study will help China to formulate its future pollution abatement policy.

The rest of the paper is arranged as follows. Section 2 elaborates the pattern of FDI inflows and pollution in China. Section 3 provides the literature review. Section 4 explains the methodology. Section 5 provides the empirical findings. The final section concludes the paper.

\section{FDI and Pollution in China}

Since its reforms for opening up its economy in 1978, the level of FDI has increased in China for last three decades. FDI, which was just $\$ 0.43$ billion in 1982 increased to $\$ 11$ billion in 1992. FDI decreased in the late 1990s, due to the Asian financial crisis, but started increasing again in the 2000s and has maintained a steady upward trend since then. FDI increased from $\$ 53$ billion in 2002 to $\$ 291$ billion in 2013, which is the highest of all time, for FDI inflows in China. In 2017, \$144 billion entered into China in terms of FDI inflows, which has made it the world's second largest recipient of FDI after the USA [25]. 
Thus, FDI has become an important component of the Chinese economy over the past three decades [11]. It has provided the financial resources for economic growth. It has stimulated technological innovations, created employment opportunities, improved the skills of laborers, promoted trade especially exports, upgraded management skills both in public and private institutions, and helped to eradicate poverty levels in the country. Figure 1 depicts the pattern of both GDP growth and FDI inflows (\% of GDP). It is evident from the figure that when FDI increases, income growth also increases, especially, after 1990 when FDI surged. Both FDI and economic growth followed the same pattern i.e., when FDI increases economic growth also increases and vice versa. FDI inflows have not only increased the overall economic growth of the country but have also increased the per capita income of the country. Figure 2 depicts the trend of both per capita income and FDI. It is clear from the figure that both FDI and per capita income follow the same pattern i.e., when FDI increases, then per capita income also increases. Per capita income, which was $\$ 203$ in 1982, it increased to $\$ 1148$ in 2002 and further increased to $\$ 8123$ in 2016 . This pattern continued until 2014, after which FDI started declining, due to the global decline in FDI inflows.

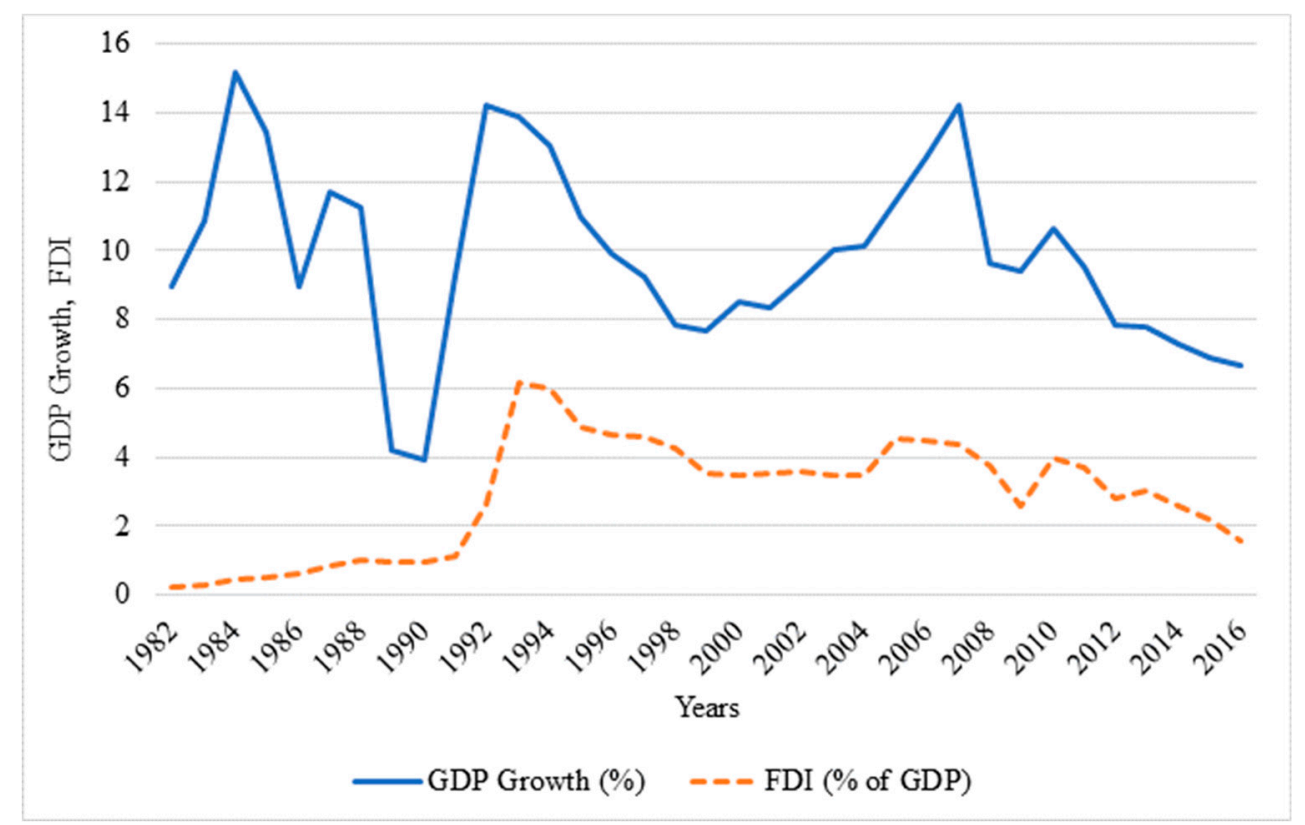

Figure 1. GDP Growth (\%) and foreign direct investment (FDI) (\% of GDP).

FDI also has some problems and impediments in China. Some important issues are regional imbalance, imbalance in sectoral distribution, abuse of transfer pricing, and implications for competition in the domestic market. This high inflow of FDI is also accompanied by environmental deterioration [6]. Most of the foreign investment is invested in pollution emitting industries, which has deteriorated the environment $[26,27]$. China has become the largest carbon emission country in the world in 2017, sharing 30\% of world carbon emissions. Carbon emissions have increased from approximately 2,442,431 (kt) in 1990 to 10,745,401 (kt) in 2016. In per capita terms, carbon emission has increased from 2.15 metric tons in 1990 to 8.09 metric tons in 2016. Figure 3 explains the pattern of carbon emissions in China, which clearly indicates that both $\mathrm{CO}_{2}(\mathrm{kt})$ and $\mathrm{CO}_{2}$ per capita (metric tons) have increased over time, in the wake of FDI inflows in the country. After joining World Trade Organization (WTO) in 2001, Chinese exports have increased globally, which has also increased carbon emissions. 


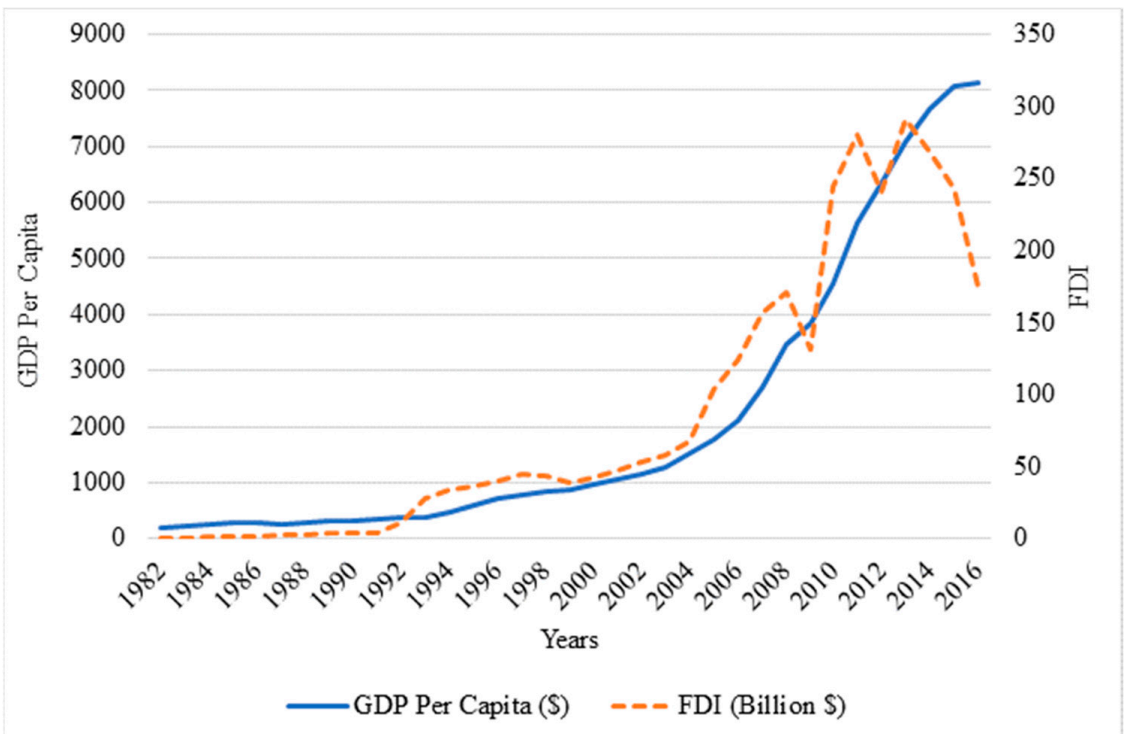

Figure 2. GDP Per Capita (\$) and FDI (Billions \$).

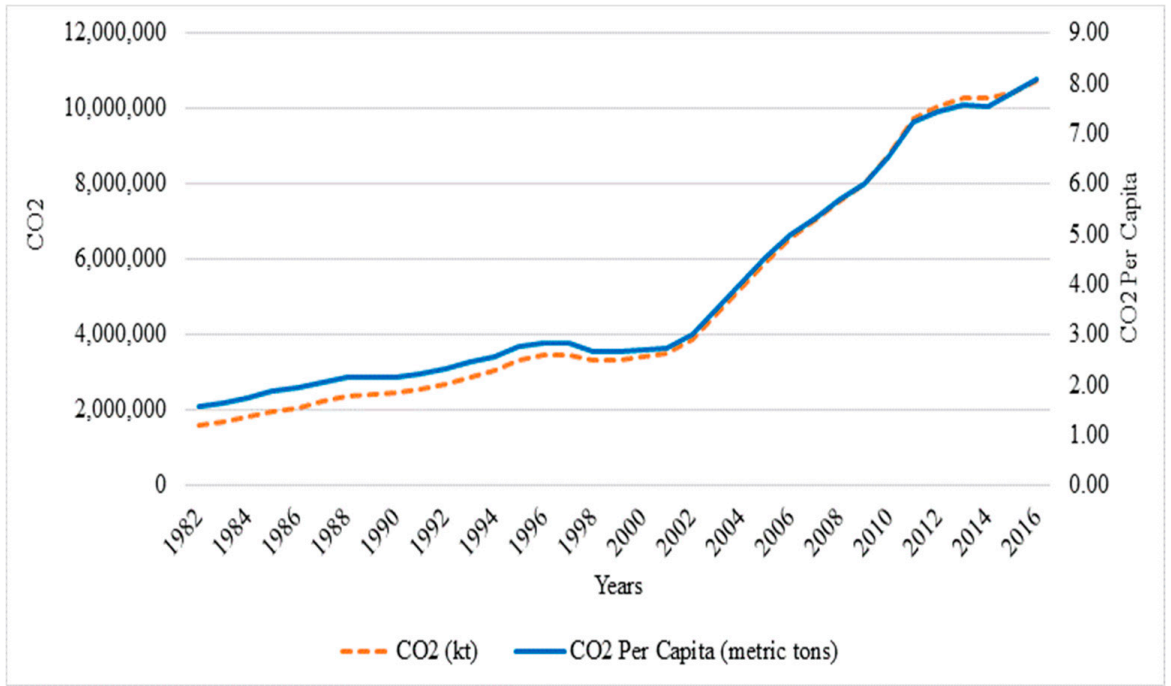

Figure 3. $\mathrm{CO}_{2}(\mathrm{kt})$ and $\mathrm{CO}_{2}$ Per Capita (metric tons).

Air pollution in China is also worst in the world and has become a threat to public health. In China, PM2.5 concentration is 5 times higher than world health organization (WHO) standards, which is 10 micrograms per cubic meters. In 2015, 1.6 million deaths occurred in China due to air pollution. In 2016, out of 338, only 84 cities maintained air quality standards. Air pollution is worst in the northern industrial provinces of the country. Figure 4 explains the pattern of $\mathrm{SO}_{2}$ emissions in China. $\mathrm{SO}_{2}$ rapidly increased in the country between 1995 and 2006, a period during which FDI inflows also surged in the country. After 2006, $\mathrm{SO}_{2}$ started declining mainly due to the adoption of flue-gas desulfurization technology by power plants. Further, China is shifting from coal, which is the major source of air pollution, to other energy sources such as hydro, wind, solar, nuclear, etc. Figure 5 explains that, like $\mathrm{SO}_{2}$, total greenhouse gas (GHG) emissions ( $\mathrm{kt}$ of $\mathrm{CO}_{2}$ equivalent) have also increased in China with the inflow of FDI. Total GHG has increased by 5 times in 2016 compared to its level in the early 1980s. GHG increased at a faster rate after 2001 when China joined the WTO. All it indicates, it that FDI has vandalized the environment in China. 


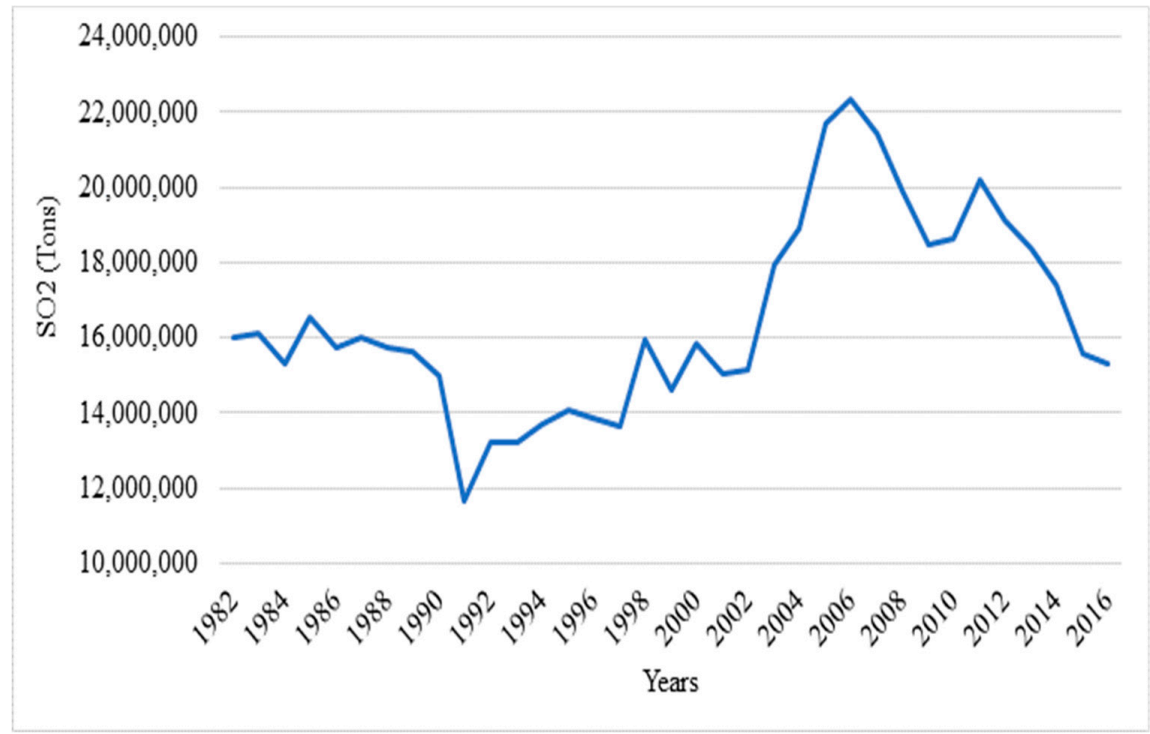

Figure 4. Sulfur Dioxide $\left(\mathrm{SO}_{2}\right)$ Emissions (tons).

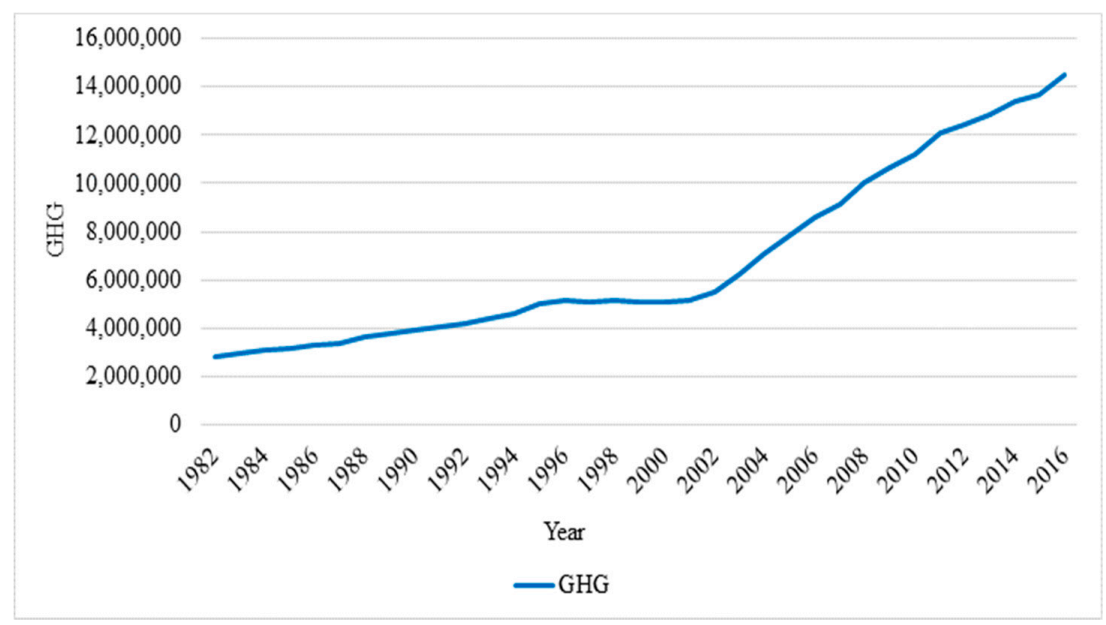

Figure 5. GHG Emissions.

Environmental damage has become a serious issue in China. China had previously shown efforts to curb pollution, but in the early 2010s, China started taking serious steps to reduce pollution. To deal with the pollution issue, the Chinese government has introduced several measures. One important step is the introduction of the electric vehicle in the country. Since 2015, China has become the global leader in sales of electric vehicles. China is also cutting excess industrial capacity, which will help to clean the environment by reducing coal consumptions. The Chinese government has also taken steps to reduce pollution in its 13th five-year plan, which was announced in November 2016. In this plan, special emphasis was given to reduce air pollution by reducing PM2.5 in the 10 worst affected cities of China by 18 percent and by reducing coal production by 140 million tons by 2020 . To alleviate air pollution China has also closed 40 percent of its industrial units which were contributing to pollution. Furthermore, the Chinese government will spend $\$ 367$ billion on renewable power projects which will also help to decrease dependence on coal consumption for power generation, to less than 40 percent by 2040, compared to the current 70 percent (Data is taken from https:/ / chinapower.csis.org/air-quality /). Previously, in 2015, an Environmental Protection Law was also introduced to curb pollution. Although the government has taken many steps to curb pollution, still more needs to be done in this regard. 


\section{Literature Review}

Empirically, many studies have examined the effect of FDI on environmental pollution. Some of them have supported the Pollution Haven Hypothesis (see e.g., [3-9,12,16,20,28-38]). Other studies have supported the Pollution Halo Hypothesis and suggest that FDI is accompanied by green technologies which improves environmental conditions [22-24,33,39-42]. According to Hoffmann et al. [43] the impact of foreign investment on pollution is contingent upon the level of development, as the pollution haven hypothesis holds only for less developed countries, not developed countries. According to Kim and Adilov [44] both the pollution haven and the pollution halo hypotheses may hold together in developing countries.

Empirical literature is also available for China. Table 1 provides a summary of the literature review for China (See Sung et al. [45] for a recent literature review for other countries). It is evident from this table that different studies have provided contradictory results. Recently, Liu et al. [46] have also shown that FDI has different effects on distinct pollutant variables, as FDI has decreased dust pollution and waste soot, while it has increased waste water and air pollution. Similarly, Yang and Wang [47] have found that FDI has increased air pollution and has decreased solid waste. Zhang and Zhou [24] documents that FDI has decreased pollution in China. Recently, Zheng and Sheng [48] have shown that FDI has increased China's pollution after market-oriented reforms. But this effect has gradually decreased over time.

Wang and Chen [11] reveal that investments from Organization for Economic Co-operation and Development (OECD) countries have increased pollution, but FDI from Hong Kong, Macau, and Taiwan (HMT) has not affected the environment. The study suggests that institutional development reduces the detrimental impacts of FDI on environment. In contrast, Huang et al. [49] have shown that FDI from HMT decreases pollution while FDI from other origins has no measurable impacts on the environment. Dean et al. [50] indicate that FDI from HMT increases pollution as FDI from these countries is attracted to areas with lax environment rules, while FDI from OECD countries decreases pollution. Lan et al. [6] show that the effect of FDI on pollution in China depends upon the level of human capital. FDI improves (deteriorates) environment in provinces which have high (low) level of human capital.

In brief, the empirical literature is inconclusive about the impact of FDI on pollution in China. This inconclusive evidence is due to differences in research objectives, estimation techniques, pollutant variables, time period, data types (panel vs. times series), heterogeneity in panels, number of provinces/cities considered, sectors covered, control variables taken, etc. Thus, there is a need to further probe the linkages between FDI and pollution in China, as China is the world's largest recipient of FDI and pollution emitting county. In this paper, our main concern is about the estimation technique, as previous studies have used traditional econometric techniques to check FDI-pollution linkages. The present study will apply a more sophisticated technique called wavelet coherence to gauge the association between these two variables. 
Table 1. Literature Review.

\begin{tabular}{|c|c|c|c|c|c|}
\hline Studies & Data Type(s) & $\begin{array}{l}\text { Time } \\
\text { Period }\end{array}$ & Main Pollutant Variable(s) & $\begin{array}{l}\text { Estimation } \\
\text { Technique }\end{array}$ & Main Finding(s) \\
\hline He [4] & Panel data for 29 provinces & 1994-2001 & $\mathrm{SO}_{2}$ & $\begin{array}{l}\text { Simultaneous } \\
\text { Equation Model }\end{array}$ & - FDI increases pollution in China. Pollution haven hypothesis is valid in China. \\
\hline Lan et al. [6] & Panel data for 29 provinces & 1996-2006 & $\mathrm{SO}_{2}$, Soot, waste water & $\begin{array}{l}\text { Fixed Effect, } \\
\text { Random Effect }\end{array}$ & $\begin{array}{l}\text { - The effect of FDI on environment depends upon human capital. } \\
\text { FDI decreases (increases) pollution in provinces which have high (low) level of } \\
\text { human capital. }\end{array}$ \\
\hline Wang and Chen [11] & Panel data for 287 Cities & 2002-2009 & $\mathrm{SO}_{2}$ & Fixed Effect Model & $\begin{array}{l}\text { - FDI from OECD countries increases pollution while FDI from HMT has no significant } \\
\text { effect on pollution. }\end{array}$ \\
\hline Zhang [12] & Times Series & 1984-2009 & $\mathrm{CO}_{2}$ & Cointegration & - FDI increases pollution in China. \\
\hline Bin and Yue [13] & Panel Data for 36 Industries & 2001-2009 & $\begin{array}{l}\mathrm{SO}_{2} \text {, industrial smoke, industrial } \\
\text { waste gas, industrial waste water, } \\
\text { COD }\end{array}$ & SYS-GMM & $\begin{array}{l}\text { - FDI reduces industrial pollution as positive technology effect is higher than the } \\
\text { negative scale and composition effects. }\end{array}$ \\
\hline Zhang and Zhou [24] & Panel data for 29 provinces & 1995-2010 & $\mathrm{CO}_{2}$ & Fixed Effect & - $\quad$ FDI reduces pollution in China. \\
\hline Liang [40] & Panel data for 260 cities & 1996-2003 & $\mathrm{SO}_{2}$ & OLS & - FDI is beneficial for environmental quality in China. \\
\hline Sung et al. [45] & $\begin{array}{c}\text { Panel data for } 28 \\
\text { manufacturing subsectors }\end{array}$ & 2002-2015 & $\mathrm{CO}_{2}$ & System GMM & $\begin{array}{l}\text { - FDI improves environmental quality in China, which supports pollution halo } \\
\text { hypothesis of FDI. }\end{array}$ \\
\hline Liu et al. [46] & Panel for 285 cities & 2003-2014 & $\begin{array}{l}\mathrm{SO}_{2} \text {, waste soot and dust, waste } \\
\text { water }\end{array}$ & $\begin{array}{l}\text { Spatial Panel Data } \\
\text { Model }\end{array}$ & $\begin{array}{l}\text { - FDI has decreased waste soot and dust pollution, while it has increased waste water } \\
\text { and } \mathrm{SO}_{2} \text {. }\end{array}$ \\
\hline Yang and Wang [47] & Panel data for 30 provinces & 2005-2014 & $\mathrm{SO}_{2}$, waste water, solid waste & GMM & - FDI and pollution have causal effect with each other. \\
\hline Zheng and Sheng [48] & Panel data for 30 provinces & 1997-2009 & $\mathrm{CO}_{2}$ & $\begin{array}{l}\text { OLS, Fixed Effect, } \\
\text { Random Effect }\end{array}$ & $\begin{array}{l}\text { - } \quad \text { FDI increases pollution in China. } \\
\text { It reduces pollution in eastern provinces while it increases pollution in four provinces } \\
\text { in west. }\end{array}$ \\
\hline Huang et al. [49] & Panel data for 30 provinces & 2001-2012 & $\begin{array}{l}\text { Pollution index (it covers waste } \\
\text { water, } \mathrm{COD} \text {, Nitrogen Oxide, } \mathrm{SO}_{2,} \\
\text { soot and dust, solid waste, } \mathrm{CO}_{2} \text { ) }\end{array}$ & $\begin{array}{l}\text { Spatial Durbin } \\
\text { Model }\end{array}$ & - FDI from abroad and HMT improves environment in China. \\
\hline Haisheng et al. [51] & Panel data for 30 provinces & 1990-2002 & $\mathrm{SO}_{2}$, Industrial Waste Water & Fixed Effect Model & - FDI deteriorates environment in China i.e., FDI increases pollution. \\
\hline Zeng and Eastin [52] & Panel data for all provinces & 1996-2004 & $\mathrm{SO}_{2}$, Solid Waste, Soot & Panel OLS & - FDI improves environmental quality in China. \\
\hline Zheng et al. [53] & Panel Data for 35 cities & 1997-2006 & Particulate Matter (PM), $\mathrm{SO}_{2}$ & OLS & - Cities in which per-capita FDI is high they have low pollution levels. \\
\hline Kirkulak et al. [54] & Panel data for 286 cities & 2001-2007 & $\mathrm{SO}_{2}$ & $\begin{array}{l}\text { Fixed Effect, } \\
\text { Random Effect }\end{array}$ & - FDI reduces air pollution in China. \\
\hline Bao et al. [55] & Panel data for 29 provinces & 1992-2004 & $\begin{array}{l}\mathrm{SO}_{2} \text {, industrial polluted water, } \\
\text { chemical oxygen demand, } \\
\text { industrial smoke, industrial solid } \\
\text { wastes }\end{array}$ & $\begin{array}{l}\text { Simultaneous } \\
\text { Equation Model }\end{array}$ & $\begin{array}{l}\text { - FDI helps reduce pollution emissions in China. However, its impact vary among } \\
\text { different regions and pollutant variables. }\end{array}$ \\
\hline Cole et al. [56] & Panel data for 112 major cities & 2001-2004 & $\begin{array}{l}\text { Wastewater, petroleum-like } \\
\text { matter, waste gas, } \mathrm{SO}_{2} \text {, soot, dust }\end{array}$ & Fixed Effect Model & - FDI from HMT reduces pollution while FDI from other countries increases pollution. \\
\hline Chang [57] & Time series & 1981-2008 & $\mathrm{SO}_{2}$, solid waste, waste water & $\begin{array}{l}\text { Vector } \\
\text { Autoregression } \\
\text { (VAR) }\end{array}$ & $\begin{array}{l}\text { - The effect of FDI on industrial pollutants vary as it depends upon the pollutant } \\
\text { variables considered. However, FDI increases solid waste. }\end{array}$ \\
\hline Jiang [58] & Panel data for 28 provinces & 1997-2012 & $\mathrm{SO}_{2}$ & Fixed Effect Model & - FDI contributes to more serious pollution emission. \\
\hline
\end{tabular}




\section{Methodology}

\subsection{Continuous Wavelet Transformation}

We probe the dynamic interaction between FDI and pollution using time-frequency analysis, namely the wavelet approach. This time-frequency approach helps to examine the dynamic links between variables over time and across different frequencies [59].

For a time series $x(t)$ the continuous wavelet transformation (CWT) for wavelet $\psi$ is expressed as:

$$
W_{x ; \psi}(\tau, s)=\int_{-\infty}^{\infty} x(t) \frac{1}{\sqrt{|s|}} \psi^{*}\left(\frac{t-\tau}{s}\right) d t
$$

$\tau$ indicates the time domain of the wavelet while $s$ indicates the frequency domain of the wavelet. In this way, wavelet transformation gives us information simultaneously about time and frequency. An important concept in the wavelet domain is the wavelet power spectrum (WPS) which is defined as follows:

$$
\operatorname{WPS}_{x}(\tau, s)=\left|W_{x}(\tau, s)\right|^{2}
$$

WPS measures the contribution at each time and scale to time series' variance.

\subsection{Wavelet Coherence and Phase Difference}

The wavelet coherence (WTC) is denoted by $R_{x y}$ and is defined as

$$
R_{x y}=\frac{\left|S\left(W_{x y}\right)\right|}{\left[S\left(\left|W_{x}\right|^{2}\right) S\left(\left|W_{y}\right|^{2}\right)\right]^{1 / 2}}
$$

with $0 \leq R_{x y}(\tau, s) \leq 1$. The phase difference $\phi_{x y}$ is defined as

$$
\phi_{x y}=\operatorname{Arctan}\left(\frac{\Im\left(W_{x y}\right)}{\Re\left(W_{x y}\right)}\right)
$$

Here $\phi_{x y}=\phi_{x}-\phi_{y}$, hence it is called phase difference. Where $\phi_{x}$ and $\phi_{y}$ are calculated as $\phi_{x}=\tan ^{-1}\left(\frac{\Im\left(W_{x}\right)}{\Re\left(W_{x}\right)}\right)$ and $\phi_{y}=\tan ^{-1}\left(\frac{\Im\left(W_{y}\right)}{\Re\left(W_{y}\right)}\right)$, respectively. This relation holds when $\phi_{x}-\phi_{y}$ is converted into an angle in the interval $[-\pi, \pi] . \Re$ and $\Im$ represent the real and imaginary part of a complex number, respectively. Two time series move together when the phase difference is zero, at a specified frequency. The series are in phase and $y$ leads $x$ when $\phi_{x, y} \in\left[0, \frac{\pi}{2}\right]$, and $x$ leads $y$ for $\phi_{x, y} \in\left[-\frac{\pi}{2}, 0\right]$, respectively. In contrast, the series are in anti-phase, when the phase difference is $\pi$ or $-\pi$. Therefore, $y$ leads $x$ for $\phi_{x, y} \in\left[-\pi,-\frac{\pi}{2}\right]$, and $x$ leads $y$ when $\phi_{x, y} \in\left[\frac{\pi}{2}, \pi\right]$, respectively.

\subsection{Wavelet Cohesion and Wavelet-Based Causality}

The causality measure is based on the CWT correlation measure of Rua [60]. The wavelet correlation measure of Rua [60] is provided as:

$$
\rho_{x y}(\tau, s)=\frac{\Re\left(W_{x y}(\tau, s)\right)}{\sqrt{\left|W_{x}(\tau, s)\right|^{2}\left|W_{y}(\tau, s)\right|^{2}}}
$$

$\rho_{x y}(\tau, s)$ lies between -1 and 1 i.e., $-1<\rho_{x y}(\tau, s)<1$. This correlation measures indicates co-movements both at frequency and over time. The Granger causality measure of Olayeni [61] in CWT framework is an extension of the wavelet-based correlation measure of Rua [60]. The CWT-Granger causality measure is expressed as: 


$$
G_{x \rightarrow y}(\tau, s)=\frac{\Re\left(W_{x y}(\tau, s)\right) I_{x \rightarrow y}(\tau, s)}{\sqrt{\left|W_{x}(\tau, s)\right|^{2}\left|W_{y}(\tau, s)\right|^{2}}}
$$

where $I_{x \rightarrow y}(\tau, s)$ denotes an indicator function, which is defined as follows:

$$
I_{x \rightarrow y}(\tau, s)=\left\{\begin{array}{c}
1, \text { if } \phi_{x y}(\tau, s) \epsilon(0, \pi / 2) \cup(-\pi,-\pi / 2) \\
0, \text { otherwise }
\end{array}\right.
$$

As can be seen, the main difference between the wavelet correlation and the CWT-Granger causality measure is the inclusion of the causal information through the indicator function $I_{x \rightarrow y}(\tau, s)$.

\section{Empirical Results}

\subsection{Data and Preliminary Statistics}

We use two measurements of FDI i.e., the amount of FDI and FDI (\% of GDP) to comprehensively capture its effect on pollution. The amount of FDI is extensively used to measure the size of foreign financial inflows in the recipient country [62]. Following Cole et al. [63], we also take FDI (\% of GDP) to see the relative importance of foreign capital inflows in the recipient country's economic activity. Since carbon emission is an important source of global pollution, we use $\mathrm{CO}_{2}$ emission to measure pollution. Two measures of $\mathrm{CO}_{2}$ emission are used i.e., $\mathrm{CO}_{2}$ emissions $(\mathrm{kt})$ and per capita $\mathrm{CO}_{2}$ emissions (metric tons). These indicators are widely used in the environmental literature. Further, we have also considered $\mathrm{SO}_{2}$ emission to measure air pollution. Data for $\mathrm{FDI}$ and $\mathrm{CO}_{2}$ variables is taken from the World Bank and the data for $\mathrm{SO}_{2}$ is taken from China Environmental Statistics Yearbooks. Initially, annual times series data is collected for the period 1982 to 2016, which is then converted into quarterly frequencies. It gives us 140 observations.

Table 2 provides the descriptive statistics of the variables. The mean value of FDI is $\$ 20.80$ billion, which ranges between 0.09 and 75.06 billion dollars. Similarly, the mean value of FDI to GDP ratio is $2.87 \%$, which ranges from $0.20 \%$ to $7.13 \%$. The mean value of per capita $\mathrm{CO}_{2}$ emission is 3.89 , which ranges between 1.55 and 8.23 metric tons per capita. FDI to GDP ratio is the only variable which is normal and all other variables are not normal, as the Jarque-Bera (JB) rejects the null hypothesis of normality for all variables except FDI to GDP ratio. Table 3 provides the correlation matrix of the variables. FDI has a high correlation with all polluting variables and this correlation is highly statistically significant. The FDI to GDP ratio also has statistically significant correlation with all polluting variables, however, the magnitude of this correlation is low compared to the correlation of FDI with pollution variables. Further, the correlation of FDI and FDI to GDP ratio is more with $\mathrm{CO}_{2}$ variables as compared to $\mathrm{SO}_{2}$.

\begin{tabular}{|c|c|c|c|c|c|}
\hline & FDI (Billion \$) & FDI ( $\%$ of GDP) & $\begin{array}{l}\mathrm{CO}_{2} \\
\text { Emissions (kt) }\end{array}$ & $\begin{array}{c}\text { Per Capita } \mathrm{CO}_{2} \\
\text { Emissions (metric tons) }\end{array}$ & $\mathrm{SO}_{2}$ (tons) \\
\hline Mean & 20.80 & 2.87 & $4,962,127$ & 3.89 & $16,503,924$ \\
\hline Median & 10.74 & 3.43 & $3,430,905$ & 2.75 & $15,957,986$ \\
\hline Maximum & 75.06 & 7.13 & $10,871,128$ & 8.23 & $22,633,287$ \\
\hline Minimum & 0.09 & 0.20 & $1,557,746$ & 1.55 & $11,407,536$ \\
\hline Std. Dev. & 23.62 & 1.70 & $3,056,166$ & 2.14 & $2,656,363$ \\
\hline Skewness & 1.05 & -0.02 & 0.76 & 0.79 & 0.52 \\
\hline Kurtosis & 2.67 & 2.12 & 2.04 & 2.08 & 2.66 \\
\hline Jarque-Bera (JB) & $26.33^{* * *}$ & 4.49 & $18.76^{* * *}$ & $19.58^{* * *}$ & $7.06^{* *}$ \\
\hline Probability (JB) & 0.00 & 0.11 & 0.00 & 0.00 & 0.03 \\
\hline Observations & 140 & 140 & 140 & 140 & 140 \\
\hline
\end{tabular}

Table 2. Descriptive Statistics of the Variables.

Note: ${ }^{* * *}\left({ }^{* *}\right)$ implies that the value is statistically significant at $1 \%(5 \%)$ level. 
Table 3. Correlation Matrix.

\begin{tabular}{ccc}
\hline & FDI (Billion \$) & FDI (\% of GDP) \\
\hline \multirow{2}{*}{$\mathrm{CO}_{2}$ Emissions (kt) } & $0.972^{* * *}$ & $0.288^{* * *}$ \\
& 48.434 & 3.538 \\
& 0.000 & 0.001 \\
\hline \multirow{2}{*}{$\mathrm{CO}_{2}$ Emissions Per Capita (metric tons) } & $0.970^{* * *}$ & $0.273^{* * *}$ \\
& 46.894 & 3.333 \\
& 0.000 & 0.001 \\
\hline \multirow{2}{*}{$\mathrm{SO}_{2}$ (tons) } & $0.499 * * *$ & $0.204^{* * *}$ \\
& 6.762 & 2.451 \\
& 0.000 & 0.015 \\
\hline
\end{tabular}

Note: ${ }^{* * *}$ implies that value is statistically significant at $1 \%$ level.

\subsection{Continuous Wavelet Transformation (CWT) Power Spectrum}

The wavelet technique measures association between two non-stationary series, therefore testing the stationarity of the variables is not necessary in a frequency-domain approach $[59,64-66]$. As evident from the previous section, all series have an increasing trend, therefore, for wavelet analysis all series are detrended by taking their log first difference. To examine the power/variance of the variables, the continuous wavelet transformation (CWT) power spectral is plotted. Figure 6 provides the CWT power spectra1 of the FDI and pollution variables. The power spectral of FDI shows that FDI has high and significant variations between 1989 and 1996 at 14-20 quarters of scale (medium frequency or medium term), and 2008-2013 at 0-14 quarters of scale (high frequency or short term to medium frequency). These frequency bands are conventional. The first 4 quarters show high frequency, 4-8 quarters show medium and more than 8 quarters show low frequency bands. Thus, FDI is found to be highly volatile in two periods, but at different frequency levels. During the first period, FDI inflows surged in China and the second period is the period after the recent financial crisis of 2007/08. More or less a similar pattern is found when FDI is taken as share of GDP. Both carbon emission variables have strong and significant power in the short run at 1-6 quarters of scale mainly between 1992-2012. Further, volatility is also high mainly in the long-run (from 32 scale onwards). Volatility for $\mathrm{SO}_{2}$ is high for the period 1987 to 2002 for 1 to 14 quarters (high to medium frequency).

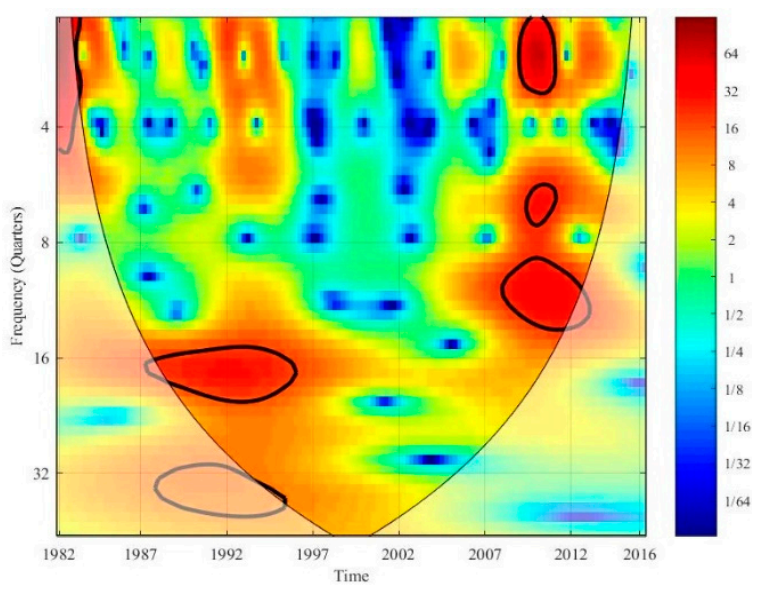

FDI (billion \$)

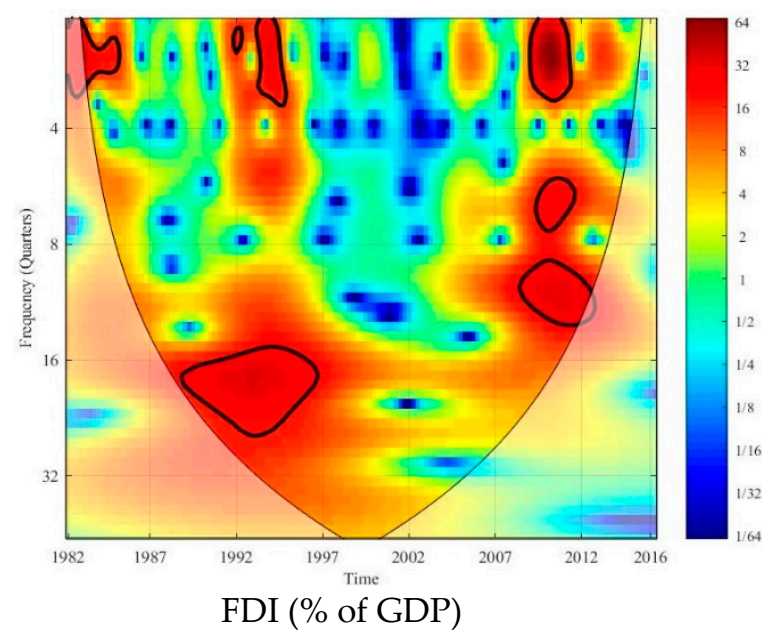

FDI (\% of GDP)

Figure 6. Cont. 


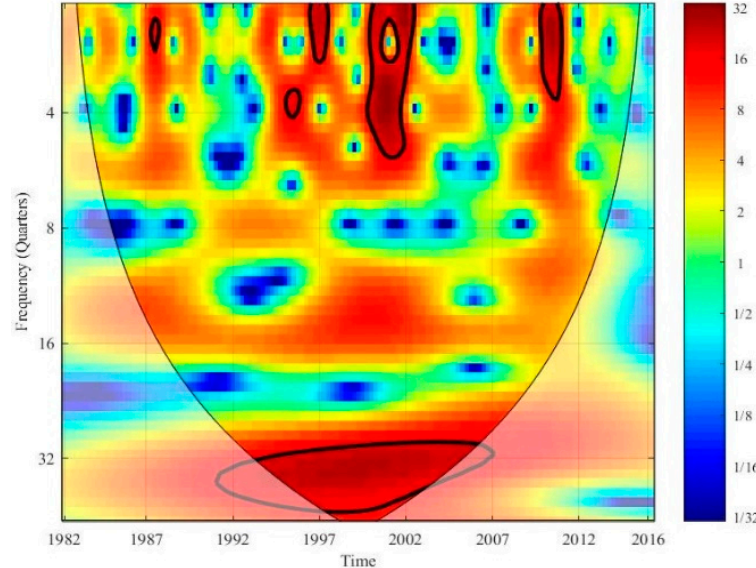

$\mathrm{CO}_{2}$ emissions $(\mathrm{kt})$

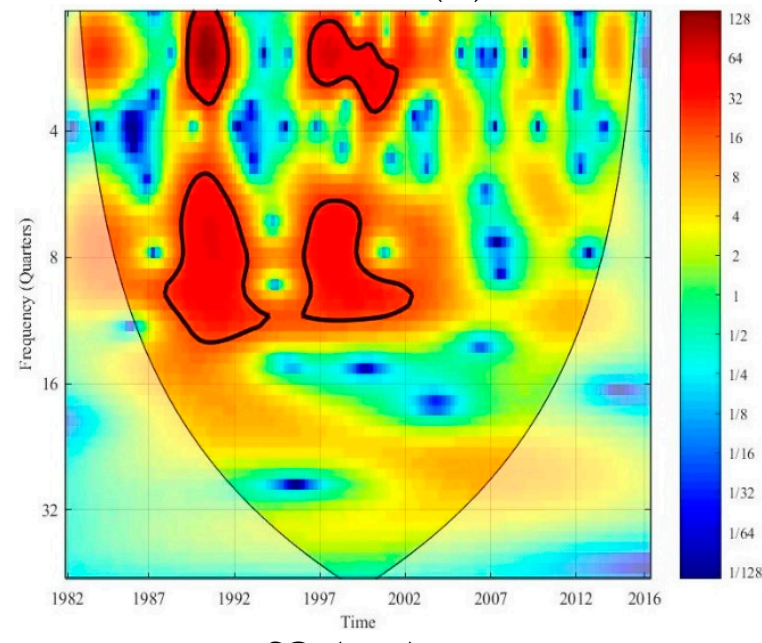

$\mathrm{SO}_{2}$ (tons)

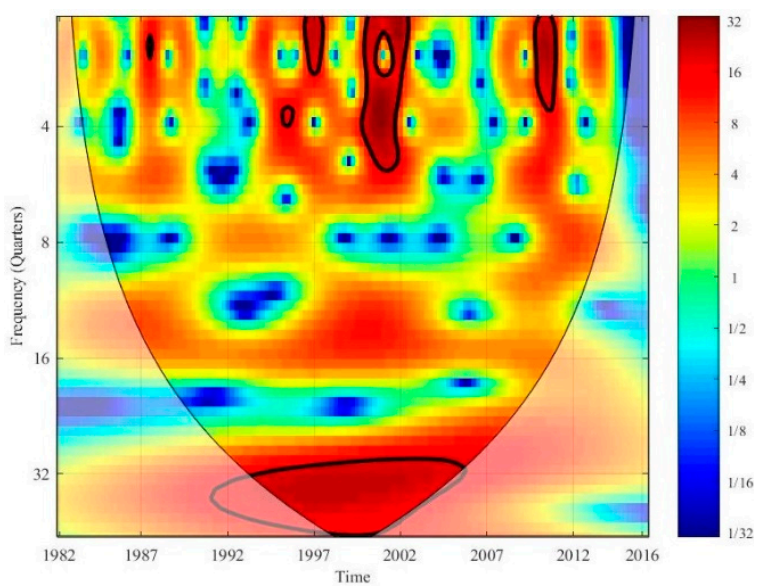

Per Capita $\mathrm{CO}_{2}$ Emissions

Figure 6. Continuous Wavelet Transformation (CWT) Power Spectrum of Time Series. Note: The 5\% significance level (against the red noise) is depicted by thick black contour. The cone of influence (COI) is shown as a lighted shadow, the area where the edge effects might distort the picture. The color bar shown on the right side of each figure indicates the color code for power that ranges from low power (in blue) to high power (in red). The study time period is on X-axis whereas the $\mathrm{Y}$-axis indicates the frequency (in quarters).

\subsection{Wavelet Coherency (WTC)}

Figure 7 provides the WTC plots. Panel A provides WTC plots of FDI with pollution variables while panel B provides the WTC plots of FDI (\% of GDP) with pollution variables. For WTC of FDI with carbon emission ( $\mathrm{kt}$ ), co-movements have been registered at frequency range of 1-3 quarters during 1984-1986, 1994-1995 and 2010-2011, and at medium frequency (medium term) 8-16 quarters during 2006-2016. The variables have cyclical effects, the arrows being oriented to right and up, FDI causes $\mathrm{CO}_{2}$ emission positively. It shows that FDI increases carbon emissions. The same results hold when per capita carbon emission is used. The results are very interesting for the case of $\mathrm{SO}_{2}$. Co-movements are found for medium frequencies from 1982 to 1997 for 16 to 22 quarters, and for frequencies 1-30 for 2007 to 2016. The arrows being oriented to right and up, FDI causes $\mathrm{SO}_{2}$ positively. It shows that FDI increases $\mathrm{SO}_{2}$ emissions. It re-enforces the hypothesis that FDI leads to pollution in China. The same results are found in Panel B when we use FDI (\% of GDP). 

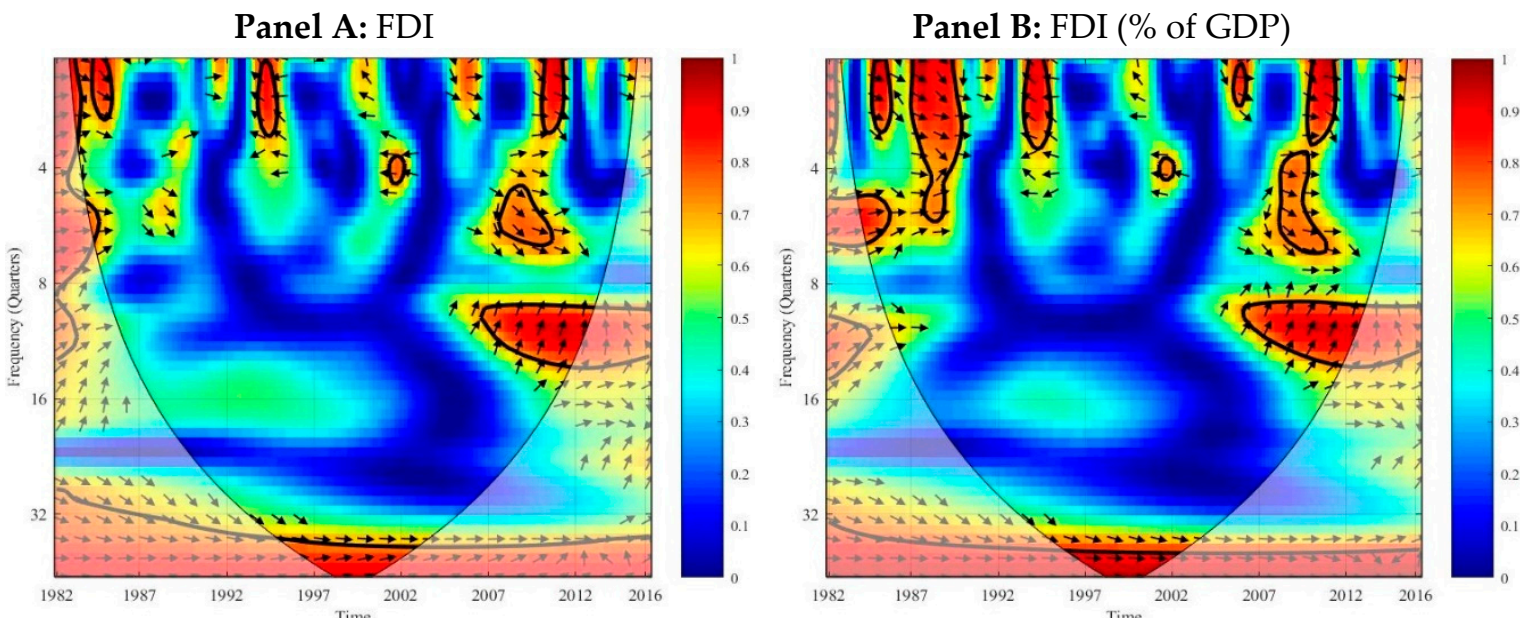

$\mathrm{CO}_{2}$ emissions $(\mathrm{kt})$
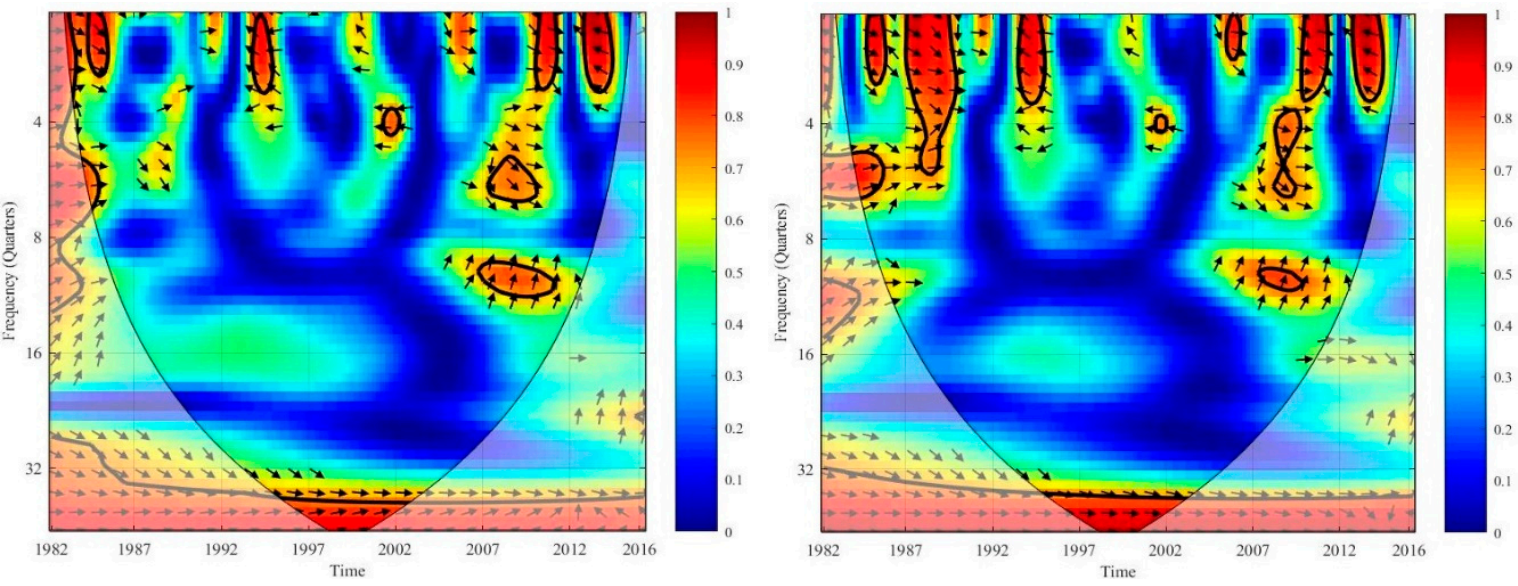

Per Capita $\mathrm{CO}_{2}$ Emissions
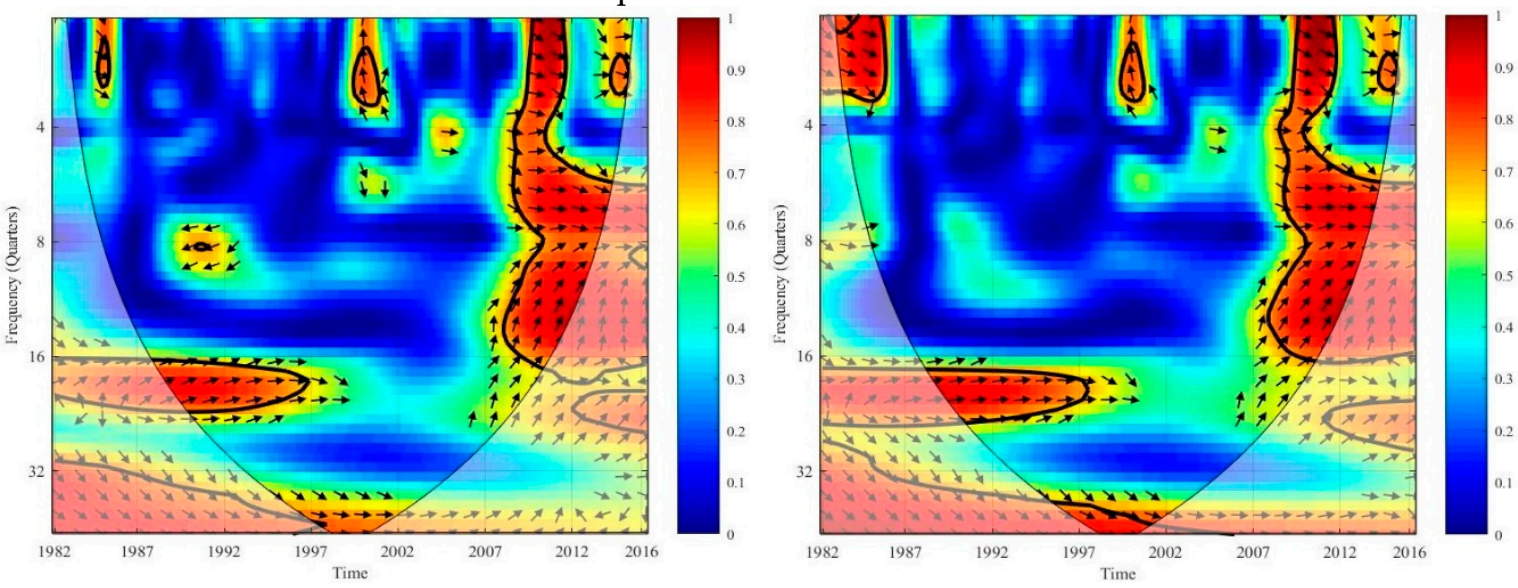

$\mathrm{SO}_{2}$ (tons)

Figure 7. Wavelet Coherency (WTC) between FDI and Pollution Variables. Note: The 5\% significance level is depicted by thick black contour which is estimated through Monte Carlo simulations following phase randomized surrogate series. The phase differences between the two series are shown through arrows. The variables are in phase (out-of-phase) when the arrows are pointed to the right (left). In phase (out-of-phase) implies a positive (negative) relationship. The FDI $\left(\mathrm{CO}_{2}\right.$ emissions) leads when the arrows point towards the right and up (right and down). The $\mathrm{CO}_{2}$ emissions (FDI) lead when the arrows are pointing towards left and up (left and down). For other details please refer to notes of previous figures. 


\subsection{Wavelet Causality and Correlations}

Figure 8 provides causality results of the wavelet transformation. Panel A presents the causal effects from FDI to pollution variables. The color code shows the strength of causal effects which runs from 0 to 1. For $\mathrm{CO}_{2}$ emission (kt) causal effect is observed between 1982 and 1990 on $26 \sim 36$ quarters and between 1983 and 2016 on 0 8 quarter frequency and this is a somewhat stronger causal effect. More or less a similar causal pattern holds with per capita $\mathrm{CO}_{2}$ emissions. However, for $\mathrm{SO}_{2}$ a strong causal effect is found between 2007 to 2016 on 0 8 quarter frequency. Panel B reports the causal flow from FDI (\% of GDP) to pollution variables. The causal effect of FDI (\% of GDP) on pollution variables is strong compared to the effect of FDI.
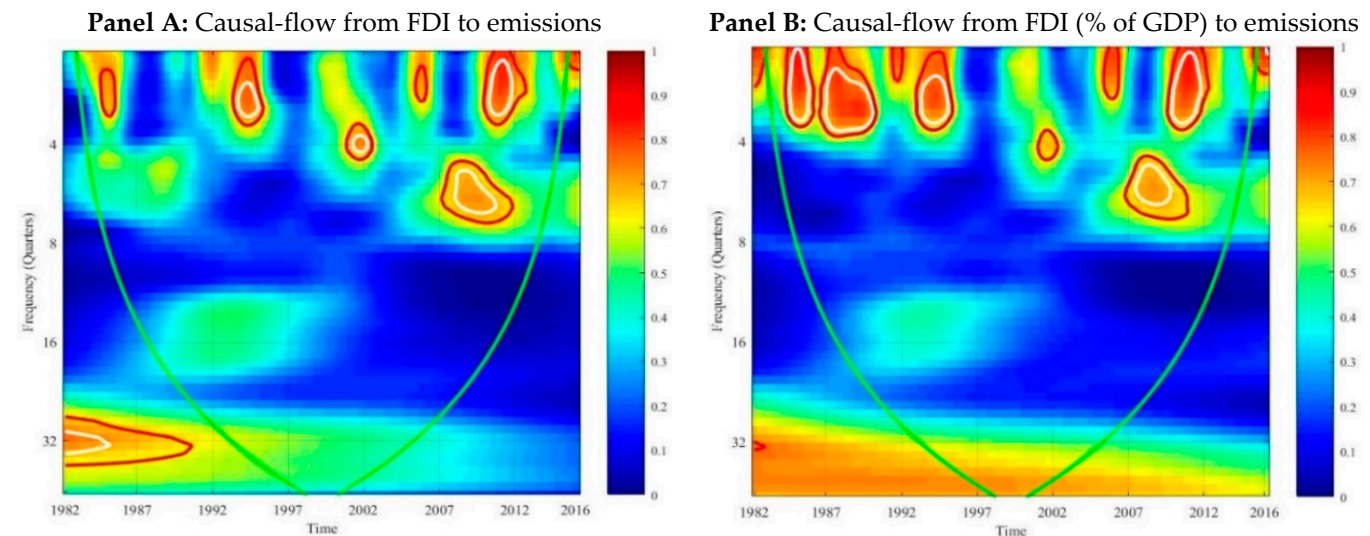

$\mathrm{CO}_{2}$ emissions $(\mathrm{kt})$
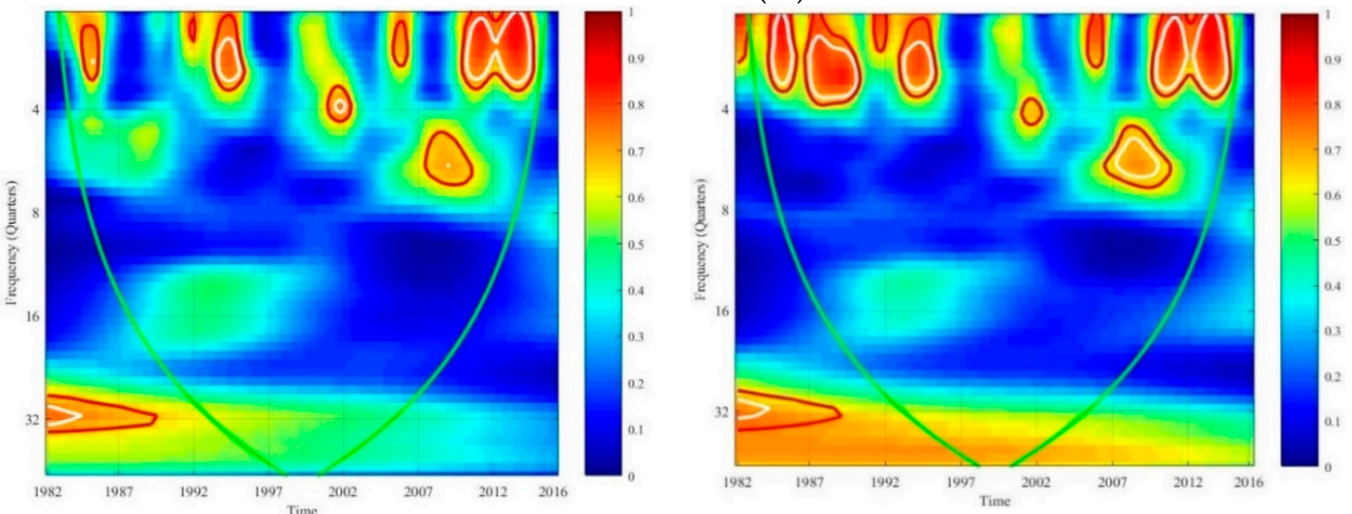

Per Capita $\mathrm{CO}_{2}$ Emissions
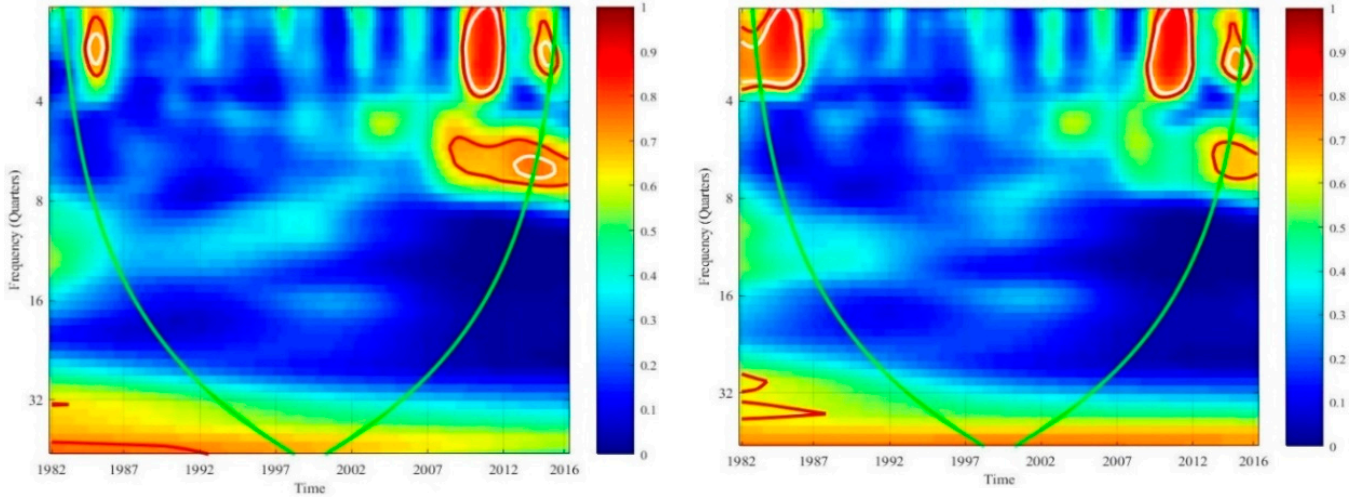

$\mathrm{SO}_{2}$ (tons)

Figure 8. Wavelet based Causality from FDI to Emissions. Note: The statistical significance at $5 \%$ and $10 \%$ level (computed based on 1000 Markov bootstrapped series) are indicated through white and red contours, respectively. For other details please refer to the notes of previous figures. 
Figure 9 reports the Rua [60] measure of CWT correlation. Panel A provides the correlation of FDI with pollution variables while Panel B provides the correlation of FDI ( $\%$ of GDP) with pollution variables. It is obvious from these plots that the period of high positive correlation between variables is the same as the periods of causal relations depicted in Figure 8. The plots generally confirm the outcomes in WTC. The first plot in Panel A shows the correlation between FDI and $\mathrm{CO}_{2}$ emission (kt). It is evident that both variables have high positive co-movements during 1982-1992, and 2005-2016 at 1-14 quarters band of scale (high and medium frequency). However, this positive co-movement is persistent for the entire time period at low frequency. No co-movement between FDI and $\mathrm{CO}_{2}$ emission is observed for the remaining sub-periods, which confirms the neutrality hypothesis during these periods. A similar interpretation holds for all variables. However, it is observed that the correlation between FDI variables and $\mathrm{SO}_{2}$ is high compared to the correlation between FDI variables and $\mathrm{CO}_{2}$ variables. It indicates that FDI has vandalized air quality more by emitting sulfur dioxide. These correlation results are somewhat in contrast with the simple correlation results given in Table 3, wherein FDI variables are highly correlated with $\mathrm{CO}_{2}$ variables, as compared to $\mathrm{SO}_{2}$ variables. However, these results are in line with the results of simple correlations that FDI variables are positively correlated with pollution variables.

Panel A: Correlation between FDI and emissions

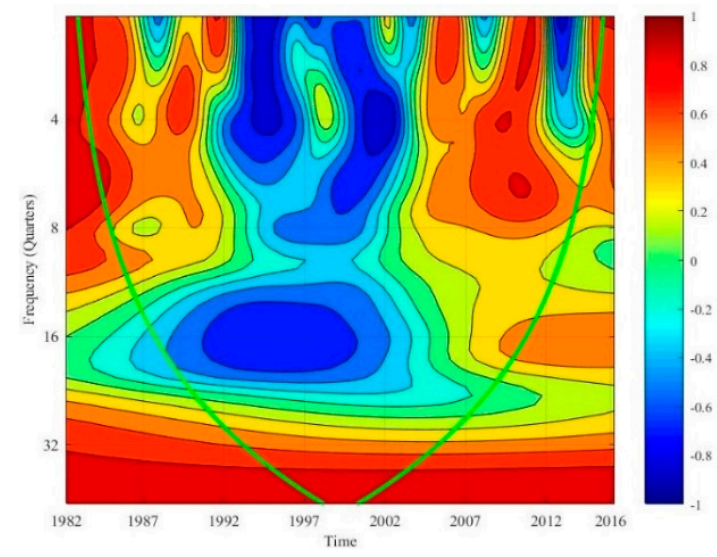

Panel B: Correlation between FDI (\% of GDP) and emissions

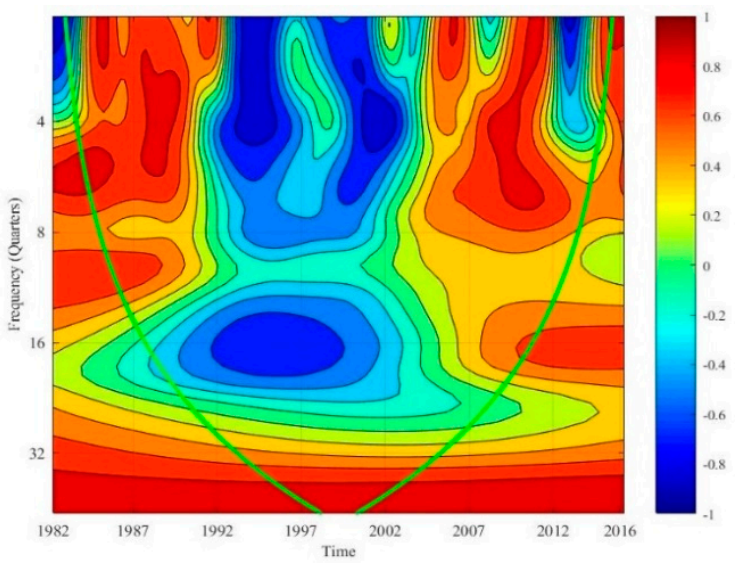

$\mathrm{CO}_{2}$ emissions (kt)
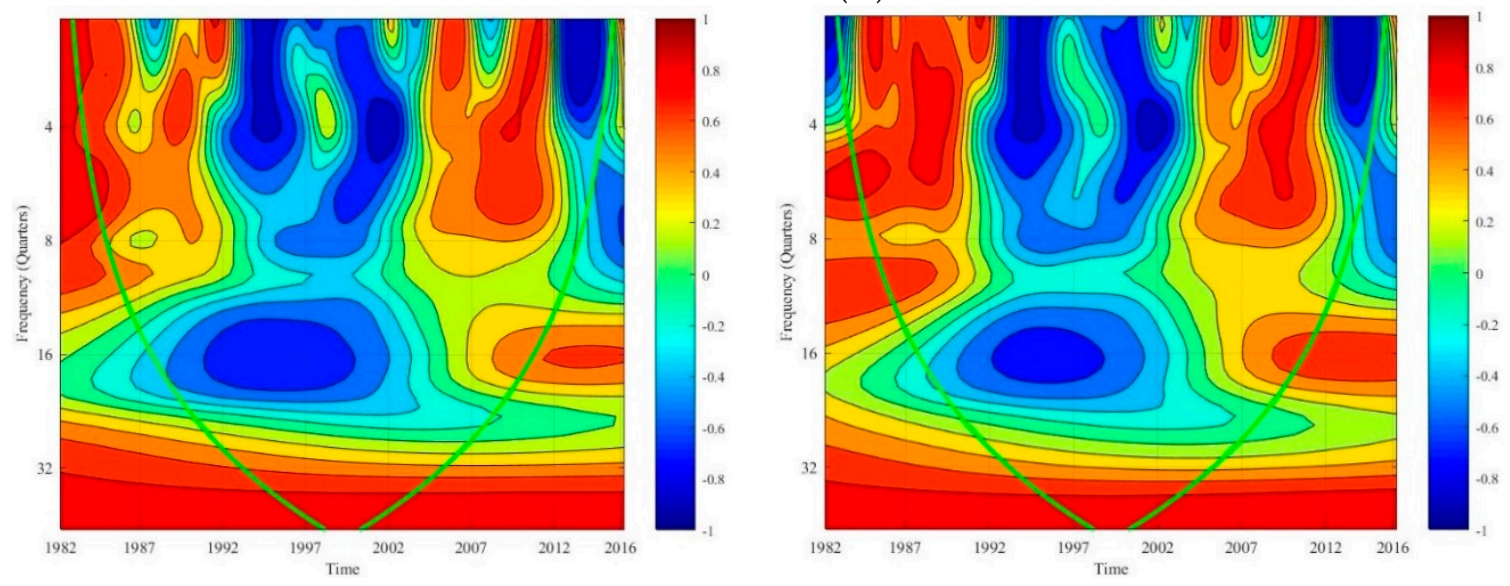

Per Capita $\mathrm{CO}_{2}$ Emissions

Figure 9. Cont. 

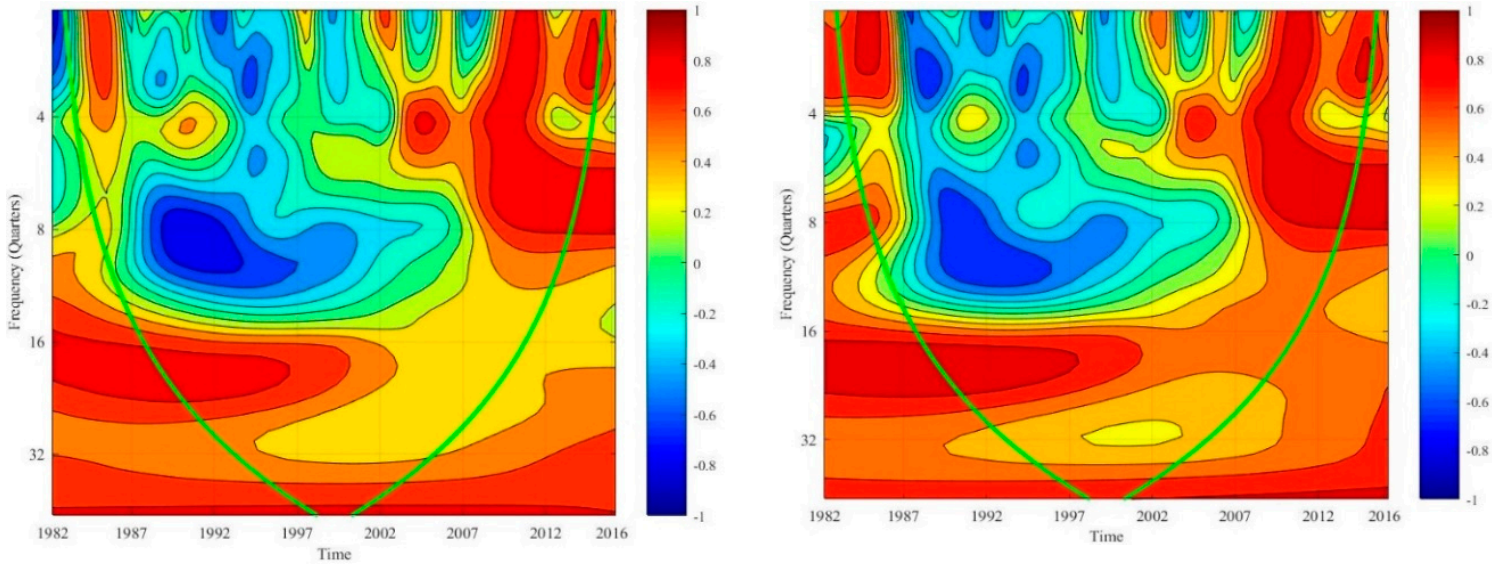

$\mathrm{SO}_{2}$ (tons)

Figure 9. Wavelet-Based Correlations [60]. Note: The figure shows the wavelet-based correlations [60]. The color code shows the degree of correlations, which goes from blue (negative correlation) to red color (positive correlation).

\subsection{Robustness Checks}

For robustness analysis, we have applied the Breitung and Candelon [67] spectral causality test. This test decomposes the causality test statistics into different frequencies. Breitung and Candelon [67] have suggested the estimation of the frequency domain causality by imposing linear restrictions on the autoregressive parameters in a Vector Autoregression (VAR) model, allowing for causality testing at different frequency bands that differ between short-, medium- and long-term. The relation between two variables $x$ and $y$, under a stationary VAR model, is explained as:

$$
\begin{aligned}
& y_{t}=\alpha_{1} y_{t-1}+\cdots+\alpha_{p} y_{t-p}+\beta_{1} x_{t-1}+\cdots+\beta_{p} x_{t-p}+\mu_{t} \\
& x_{t}=\gamma_{1} x_{t-1}+\cdots+\gamma_{p} x_{t-p}+\theta_{1} y_{t-1}+\cdots+\theta_{p} y_{t-p}+v_{t}
\end{aligned}
$$

The Granger causality from $x$ to $y$ at any frequency $(\omega)$ can be tested under the linear restriction $H_{0}: R(\omega) \beta=0$, where $\beta=\left|\beta_{1}, \ldots \beta_{p}\right|^{\prime}$ given by:

$$
R(\omega)=\left(\begin{array}{ll}
\cos (\omega) & \cos (2 \omega) \ldots \cos (p \omega) \\
\sin (\omega) & \sin (2 \omega) \ldots \sin (p \omega)
\end{array}\right)
$$

In this test, the null hypothesis, in the frequency interval $\omega \in(0, \pi)$, is tested using the F-statistics, which are approximately distributed as $F(2, T-2 p)$. Recently, Bouri et al. [68] have used this test to analyze short and long run causality between gold and stock markets of India and China.

Figure 10 provides the results of the causality test. The results from this causality test are similar to those given in Figure 8. The first plot in panel A shows that FDI causes $\mathrm{CO}_{2}$ emissions both in shortand long-runs within $(0.65,1.48)$ and $(2.12,2.51)$ frequency bands. This suggests that in China FDI predicts the $\mathrm{CO}_{2}$ emissions. The same results hold for when FDI is taken as share of GDP in which FDI causes $\mathrm{CO}_{2}$ emissions both in short- and long-terms within $(0.72,0.98)$ and $(2.19,2.68)$ frequency bands. However, the causality from FDI to $\mathrm{CO}_{2}$ emission is more obvious than is the causality from FDI (\% of GDP) to $\mathrm{CO}_{2}$ emissions in short-run. These frequency domain causality results mainly confirm (with few exceptions) the wavelets result, namely that FDI mostly impacts in the short-run (high frequency) and long-run (low frequency), not the medium term. This finding is not surprising, given that China is the second largest FDI recipient and the world's largest carbon emitter. These results suggest that the government in China should design the FDI policies while having a closer look at the environmental consequences of capital inflows. 
FDI does not cause per capita $\mathrm{CO}_{2}$ emission in short and long runs. This result also holds for when FDI is taken as share of GDP. FDI has no effect on $\mathrm{SO}_{2}$ in the long term and has little effect in the short term. FDI (\% of GDP) has no effect on $\mathrm{SO}_{2}$ in short and long terms.

Panel A: FDI-Net inflows (BoP, current US\$) Panel B: FDI-Net inflows (\% of GDP)
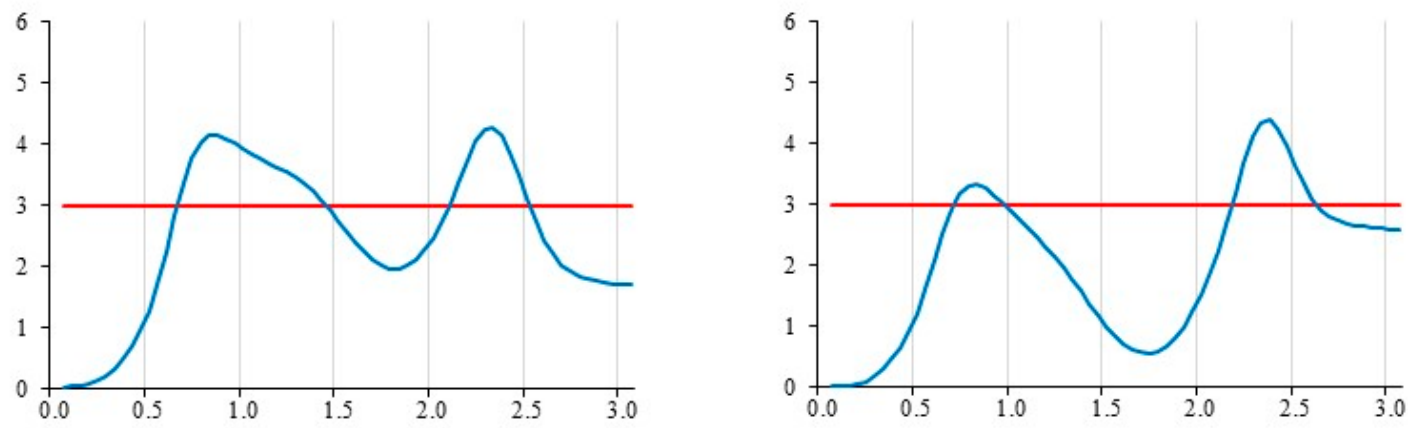

$\mathrm{CO}_{2}$ emissions (kt)
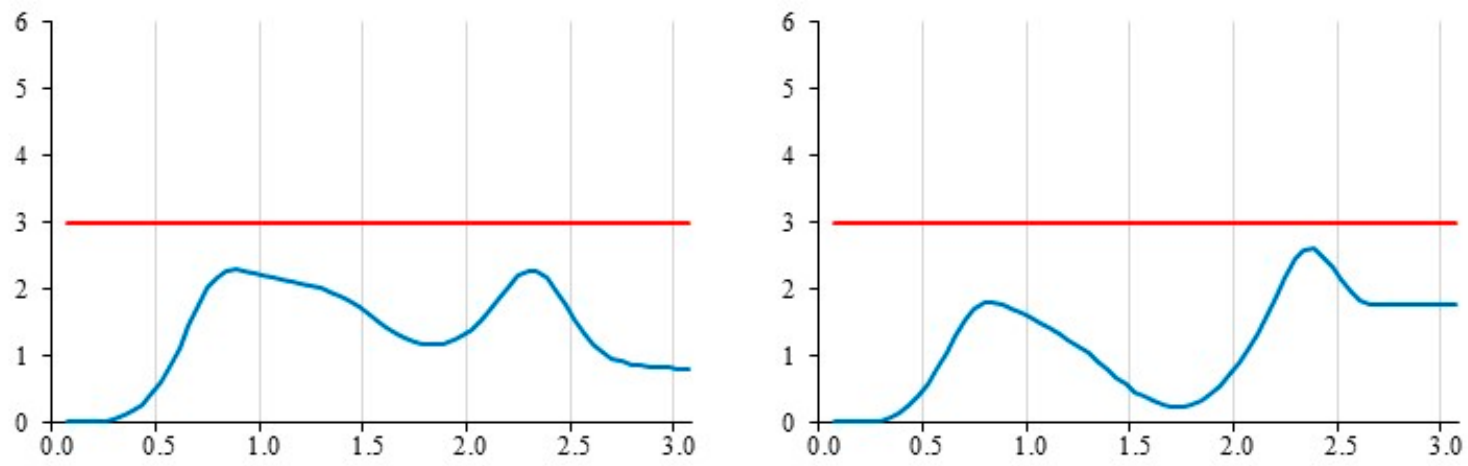

Per Capita $\mathrm{CO}_{2}$ Emissions
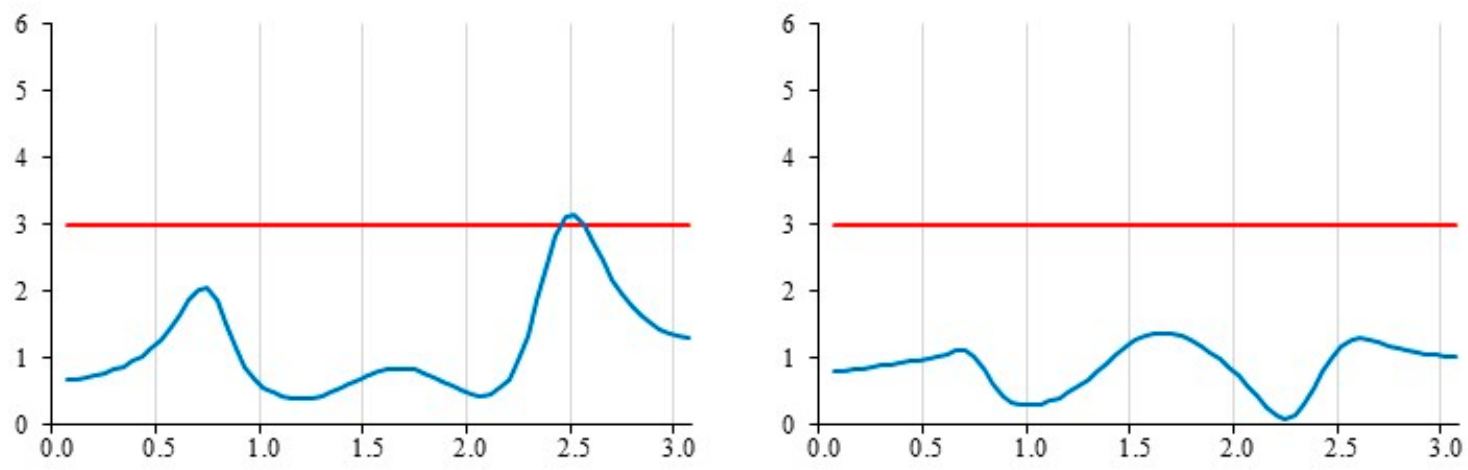

$\mathrm{SO}_{2}$ (tons)

Figure 10. Short Run and Long Run Causality Test in Frequency Domain from FDI to Emissions. Note: The frequencies (omega) are on $\mathrm{x}$-axis and $\mathrm{y}$-axis show the $\mathrm{F}$ statistics testing the null hypothesis of no Granger-causality. The horizontal red line indicates the 5\% critical values.

\section{Conclusions}

The paper explores the effect of FDI on pollution in China using data for the period 1982 to 2016 by applying the wavelet tool. The main findings reveal that FDI positively drives the pollution at high and low frequencies, which confirms the 'pollution haven hypothesis' for short and long terms. At low frequency, FDI provoked pollution during the 1980s in the wake of economic reforms when FDI inflows started to increase, and after 2000 due to a surge in FDI and high economic growth which increased production after the joining of WTO by China in 2001. It accelerated the FDI flows 
of dirty industries and led to both scale and composition effects. Hence, for the short and long term, lax environment regulations have stimulated FDI in polluting industries. Interestingly, FDI has no effect on pollution at medium frequency. These results support the findings of some previous studies showing that FDI increases pollution in China $[4,12,51,58]$. For robustness analysis, spectral causality analysis was conducted and the results of this spectral causality test indicate that FDI causes $\mathrm{CO}_{2}$ emissions both in the short-run and long-run. It suggests that FDI predicts $\mathrm{CO}_{2}$ emissions in China.

The study has some important policy implications. The government should introduce strict environmental regulations to restrict the entry of pollution industries in the country. The government should also introduce rules so that local firms receiving FDI may adopt and exchange green technology. These measures will help reduce pollution in the country. Further, government should promote education, which will help to reduce pollution. Government should provide incentives to local firms to increase research and development $(\mathrm{R} \& \mathrm{D})$ investment; it will strengthen the technical efficiency of the host economy, which will lower pollution in China.

Author Contributions: All authors contributed to data collection, estimation, writing and editing of this study. The idea, initial work and data collection are carried out by M.Z. and H.M. The analysis and supportive work is done by S.J.H.S. Critical review and amendments in the draft from W.J. significantly improved the quality of the study.

Funding: This research received no external funding.

Conflicts of Interest: The authors declare no conflicts of interest.

\section{References}

1. Copeland, B.R.; Taylor, M.S. North-South Trade and the Environment. Q. J. Econ. 1994, 109, 755-787. [CrossRef]

2. Tobey, J.A. Effects of Domestic Environmental Policy on Patterns of International Trade: An Empirical Test. Kyklos Int. Rev. Soc. Sci. 1990, 43, 191-2019.

3. Cole, M.A. Trade, the pollution haven hypothesis and the environmental Kuznets curve: Examining the linkages. Ecol. Econ. 2004, 48, 71-81. [CrossRef]

4. He, J. Pollution haven hypothesis and environmental impacts of foreign direct investment: The case of industrial emission of sulfur dioxide $\left(\mathrm{SO}_{2}\right)$ in Chinese provinces. Ecol. Econ. 2006, 60, 228-245. [CrossRef]

5. Kivyiro, P.; Arminen, H. Carbon dioxide emissions, energy consumption, economic growth, and foreign direct investment: Causality analysis for Sub-Saharan Africa. Energy 2014, 74, 595-606. [CrossRef]

6. Lan, J.; Kakinaka, M.; Huang, X. Foreign Direct Investment, Human Capital and Environmental Pollution in China. Environ. Resour. Econ. 2012, 51, 255-275. [CrossRef]

7. Levinson, A.; Taylor, M.S. Unmasking the Pollution Haven Effect. Int. Econ. Rev. 2008, 49, 223-254. [CrossRef]

8. Omri, A.; Nguyen, D.K.; Rault, C. Causal interactions between $\mathrm{CO}_{2}$ emissions, FDI, and economic growth: Evidence from dynamic simultaneous-equation models. Econ. Model. 2014, 42, 382-389. [CrossRef]

9. Shahbaz, M.; Nasreen, S.; Abbas, F.; Anis, O. Does foreign direct investment impede environmental quality in high-, middle- and low-income countries? Energy Econ. 2015, 51, 275-287. [CrossRef]

10. Tang, C.F.; Tan, B.W. The impact of energy consumption, income and foreign direct investment on carbon dioxide emissions in Vietnam. Energy 2015, 79, 447-454. [CrossRef]

11. Wang, D.T.; Chen, W.Y. Foreign direct investment, institutional development, and environmental externalities: Evidence from China. J. Environ. Manag. 2014, 135, 81-90. [CrossRef] [PubMed]

12. Zhang, Y.J. The impact of financial development on carbon emissions: An empirical analysis in China. Energy Policy 2011, 39, 2197-2203. [CrossRef]

13. Bin, S.; Yue, L. Impact of foreign direct investment on china's environment: An empirical study based on industrial panel data. Soc. Sci. China 2012, 33, 89-107. [CrossRef]

14. Javorcik, B.S.; Wei, S.-J. Pollution havens and foreign direct investment: Dirty secret or popular myth? Contrib. Econ. Anal. Policy 2004, 3, 1-32. [CrossRef]

15. Antweiler, W.; Copeland, B.R.; Taylor, S. Is free trade good for the environnement. Am. Econ. Rev. 2001, 91, 807-908. [CrossRef] 
16. Eskeland, G.S.; Harrison, A.E. Moving to greener pastures? Multinationals and the pollution haven hypothesis. J. Dev. Econ. 2003, 70, 1-23. [CrossRef]

17. Grossman, G.M.; Krueger, A.B. Environmental Impacts of a North American Free Trade Agreement; NBER Working Paper No. 3914; MIT Press: Cambridge, MA, USA, 1991; pp. 1-57.

18. Araya, M. FDI and the environment: What empirical evidence does-And does not-Tell us. In International Investment for Sustainable Development Balancing Rights and Rewards; Routledge: London, UK, 2012; pp. 46-73.

19. Zhu, Q.; Sarkis, J.; Lai, K.H. Initiatives and outcomes of green supply chain management implementation by Chinese manufacturers. J. Environ. Manag. 2007, 85, 179-189. [CrossRef] [PubMed]

20. Al-mulali, U. Factors affecting $\mathrm{CO}_{2}$ emission in the Middle East: A panel data analysis. Energy 2012, 44, 564-569. [CrossRef]

21. Cole, M.A.; Elliott, R.J.R. FDI and the capital intensity of "dirty" sectors: A missing piece of the pollution haven puzzle. Rev. Dev. Econ. 2005, 9, 530-548. [CrossRef]

22. Al-mulali, U.; Tang, C.F. Investigating the validity of pollution haven hypothesis in the gulf cooperation council (GCC) countries. Energy Policy 2013, 60, 813-819. [CrossRef]

23. Tamazian, A.; Chousa, J.P.; Vadlamannati, K.C. Does higher economic and financial development lead to environmental degradation: Evidence from BRIC countries. Energy Policy 2009, 37, 246-253. [CrossRef]

24. Zhang, C.; Zhou, X. Does foreign direct investment lead to lower $\mathrm{CO}_{2}$ emissions? Evidence from a regional analysis in China. Renew. Sustain. Energy Rev. 2016, 58, 943-951. [CrossRef]

25. UNCTAD. World Investment Report; United Nations Conference on Trade and Development: Geneva, Switzerland, 2018.

26. Li, M.; Zhang, L. Haze in China: Current and future challenges. Environ. Pollut. 2014, 189, 85-86. [CrossRef] [PubMed]

27. Liu, Q.; Wang, Q. How China achieved its 11th Five-Year Plan emissions reduction target: A structural decomposition analysis of industrial $\mathrm{SO}_{2}$ and chemical oxygen demand. Sci. Total. Environ. 2017, 574, 1104-1116. [CrossRef] [PubMed]

28. Acharyya, J. FDI, Growth and the environment: Evidence from India on $\mathrm{CO}_{2}$ emission during the last two decades. J. Econ. Dev. 2009, 34, 43-58.

29. Akbostanci, E.; Tunç, G.I.; Türüt-Aşik, S. Pollution haven hypothesis and the role of dirty industries in Turkey's exports. Environ. Dev. Econ. 2007, 12, 297-322. [CrossRef]

30. Baek, J.; Cho, Y.; Koo, W.W. The environmental consequences of globalization: A country-specific time-series analysis. Ecol. Econ. 2009, 68, 2255-2264. [CrossRef]

31. Chung, S. Environmental regulation and foreign direct investment: Evidence from South Korea. J. Dev. Econ. 2014, 108, 222-236. [CrossRef]

32. Hitam, M.B.; Borhan, H.B. FDI, Growth and the Environment: Impact on Quality of Life in Malaysia. Procedia Soc. Behav. Sci. 2012, 50, 333-342. [CrossRef]

33. List, J.A.; Co, C.Y. The effects of environmental regulations on foreign direct investment. J. Environ. Econ. Manag. 2000, 40, 1-20. [CrossRef]

34. Pao, H.T.; Tsai, C.M. Multivariate Granger causality between $\mathrm{CO}_{2}$ emissions, energy consumption, FDI (foreign direct investment) and GDP (gross domestic product): Evidence from a panel of BRIC (Brazil, Russian Federation, India, and China) countries. Energy 2011, 36, 685-693. [CrossRef]

35. Smarzynska, B.K.; Wei, S. Pollution Havens and Foreign Direct Investment: Dirty Secret or Popular Myth? National Bureau of Economic Research: Cambridge, MA, USA, 2001.

36. Xing, Y.; Kolstad, C.D. Do lax environmental regulations attract foreign investment? Environ. Resour. Econ. 2002, 21, 1-22. [CrossRef]

37. Zeng, D.Z.; Zhao, L. Pollution havens and industrial agglomeration. J. Environ. Econ. Manag. 2009, 58, 141-153. [CrossRef]

38. Zhang, J.; Fu, X. Do Intra-Country Pollution Havens Exist? FDI and Environmental Regulations in China; SLPTMD Working Paper Series No. 013; Department of International Development, University of Oxford: Oxford, UK, 2008.

39. Lee, C.G. Foreign direct investment, pollution and economic growth: Evidence from Malaysia. Appl. Econ. 2009, 41, 1709-1716. [CrossRef]

40. Liang, F.H. Does Foreign Direct Investment Harm the Host Country's Environment? Evidence from China. 2008. Available online: https:/ / ssrn.com/abstract=1479864 (accessed on 9 July 2018). 
41. Merican, Y.; Yusop, Z.; Mohd Noor, Z.; Siong Hook, L. Foreign direct investment and the pollution in Five ASEAN nations. Int. J. Econ. Manag. 2007, 1, 245-261.

42. Sbia, R.; Shahbaz, M.; Hamdi, H. A contribution of foreign direct investment, clean energy, trade openness, carbon emissions and economic growth to energy demand in UAE. Econ. Model. 2014, 36, 191-197. [CrossRef]

43. Hoffmann, R.; Lee, C.; Ramasamy, B.; Yeung, M. FDI and pollution: A granger causality test using panel data. J. Int. Dev. 2005, 17, 311-317. [CrossRef]

44. Kim, M.H.; Adilov, N. The lesser of two evils: An empirical investigation of foreign direct investment-pollution tradeoff. Appl. Econ. 2012, 44, 2597-2606. [CrossRef]

45. Sung, B.; Song, W.Y.; Park, S.-D. How foreign direct investment affects $\mathrm{CO}_{2}$ emission levels in the Chinese manufacturing industry: Evidence from panel data. Econ. Syst. 2018, 42, 320-331. [CrossRef]

46. Liu, Q.; Wang, S.; Zhang, W.; Zhan, D.; Li, J. Does foreign direct investment affect environmental pollution in China's cities? A spatial econometric perspective. Sci. Total Environ. 2018, 613-614, 521-529. [CrossRef] [PubMed]

47. Yang, J.; Wang, Y. FDI and Environmental Pollution Nexus in China. Master's Thesis, Lund University, Lund, Sweden, 2016; pp. 1-47.

48. Zheng, J.; Sheng, P. The Impact of Foreign Direct Investment (FDI) on the Environment: Market Perspectives and Evidence from China. Economies 2017, 5, 8. [CrossRef]

49. Huang, J.; Chen, X.; Huang, B.; Yang, X. Economic and environmental impacts of foreign direct investment in China: A spatial spillover analysis. China Econ. Rev. 2017, 45, 289-309. [CrossRef]

50. Dean, J.; Mary, L.; Wang, H. Are foreign investors attracted to weak environmental regulations? Evaluating the evidence from China. J. Dev. Econ. 2009, 90, 1-13. [CrossRef]

51. Haisheng, Y.; Jia, J.; Yongzhang, Z.; Shugong, W. The impact on environmental kuznets curve by trade and foreign direct investment in China. Chin. J. Popul. Resour. Environ. 2005, 3, 14-19. [CrossRef]

52. Zeng, K.; Eastin, J. International Economic Integration and Environmental Protection: The Case of China. Int. Stud. Q. 2007, 51, 971-995. [CrossRef]

53. Zheng, S.; Kahn, M.E.; Liu, H. Regional Science and Urban Economics Towards a system of open cities in China: Home prices, FDI flows and air quality in 35 major cities. Reg. Sci. Urban Econ. 2010, 40, 1-10. [CrossRef]

54. Kirkulak, B.; Qiu, B.; Yin, W. The impact of FDI on air quality: Evidence from China. J. Chin. Econ. Foreign Trade Stud. 2011, 4, 81-98. [CrossRef]

55. Bao, Q.; Chen, Y.; Song, L. Foreign direct investment and environmental pollution in China: A simultaneous equations estimation. Environ. Dev. Econ. 2011, 16, 71-92. [CrossRef]

56. Cole, M.A.; Elliott, R.J.R.; Zhang, J. Growth, foreign direct investment, and the environment: Evidence from chinese cities. J. Reg. Sci. 2011, 51, 121-138. [CrossRef]

57. Chang, N. The empirical relationship between openness and environmental pollution in China. J. Environ. Plan. Manag. 2012, 55, 783-796. [CrossRef]

58. Jiang, Y. Foreign direct investment, pollution, and the environmental quality: A model with empirical evidence from the Chinese regions. Int. Trade J. 2015, 29, 212-227. [CrossRef]

59. Aguiar-Conraria, L.; Azevedo, N.; Soares, M.J. Using wavelets to decompose the time-frequency effects of monetary policy. Phys. A Stat. Mech. Appl. 2008, 387, 2863-2878. [CrossRef]

60. Rua, A. Worldwide synchronization since the nineteenth century: A wavelet-based view. Appl. Econ. Lett. 2013, 20, 773-776. [CrossRef]

61. Olayeni, O.R. Causality in Continuous Wavelet Transform Without Spectral Matrix Factorization: Theory and Application. Comput. Econ. 2016, 47, 321-340. [CrossRef]

62. Lee, J.W. The contribution of foreign direct investment to clean energy use, carbon emissions and economic growth. Energy Policy 2013, 55, 483-489. [CrossRef]

63. Cole, M.A.; Elliott, R.J.R.; Okubo, T.; Zhou, Y. The carbon dioxide emissions of firms: A spatial analysis. J. Environ. Econ. Manag. 2013, 65, 290-309. [CrossRef]

64. Boashash, B. Time-Frequency Signal Analysis and Processing, 2nd ed.; Academic Press: Cambridge, MA, USA, 2015.

65. Crowley, P.M.; Mayes, D.G. How fused is the euro area core? An evaluation of growth cycle co-movement and synchronization using wavelet analysis. OECD J. J. Bus. Cycle Meas. Anal. 2008, 4, 63-95. 
66. Hallett, A.H.; Richter, C. Have the Eurozone economies converged on a common European cycle? Int. Econ. Econ. Policy 2008, 5, 71-101. [CrossRef]

67. Breitung, J.; Candelon, B. Testing for short- and long-run causality: A frequency-domain approach. J. Econ. 2006, 132, 363-378. [CrossRef]

68. Bouri, E.; Roubaud, D.; Jammazi, R.; Assaf, A. Uncovering frequency domain causality between gold and the stock markets of China and India: Evidence from implied volatility indices. Financ. Res. Lett. 2017, 23, 23-30. [CrossRef]

(c)

(C) 2018 by the authors. Licensee MDPI, Basel, Switzerland. This article is an open access article distributed under the terms and conditions of the Creative Commons Attribution (CC BY) license (http:/ / creativecommons.org/licenses/by/4.0/). 